\title{
Activity-Dependent Presynaptic Effect of Serotonin 1B Receptors on the Somatosensory Thalamocortical Transmission in Neonatal Mice
}

\author{
Alban Laurent,, Jean-Marc Goaillard, ${ }^{1}$ Olivier Cases, ${ }^{2}$ Cécile Lebrand, ${ }^{2}$ Patricia Gaspar, ${ }^{2}$ and Nicole Ropert ${ }^{1}$ \\ ${ }^{1}$ Laboratoire de Neurophysiologie et Nouvelles Microscopies, Institut National de la Santé et de la Recherche Médicale \\ (INSERM) EPI-0002, Ecole Supérieure de Physique et de Chimie Industrielle, 75231 Paris cedex 5, France, and 2INSERM \\ U106, Bât. Pédiatrie, Hôpital Pitié Salpétrière, 75651 Paris cedex 13, France
}

The disruptive effect of excessive serotonin (5-HT) levels on the development of cortical sensory maps is mediated by $5-\mathrm{HT} 1 \mathrm{~B}$ receptors, as shown in barrelless monoamine oxidase A knockout mice, in which the additional inactivation of 5-HT1B receptors restores the barrels. However, it is unclear whether 5-HT1B receptors mediate their effect on barrel formation by a trophic action or an activity-dependent effect.

To test for a possible effect of 5-HT1B receptors on activity, we studied the influence of 5-HT on the thalamocortical (TC) synaptic transmission in layer IV cortical neurons. In TC slices of postnatal day 5 (P5)-P9 neonate mice, we show that 5-HT reduces monosynaptic TC EPSCs evoked by low-frequency internal capsule stimulation and relieves the short-term depression of the EPSC evoked by high-frequency stimulation. We provide evidence that $5-\mathrm{HT}$ decreases the presynaptic release of glutamate: 5-HT reduces similarly the AMPA-kainate and NMDA components and the paired pulse depression of TC EPSCs. We show also that $5-\mathrm{HT} 1 \mathrm{~B}$ receptors mediate exclusively the effect of 5-HT: first, the effect of 5-HT on the TC EPSC is correlated with the transient expression of $5-\mathrm{HT} 1 \mathrm{~B}$ receptor mRNAs in the ventrobasal thalamic nucleus during postnatal development; second, it is mimicked by a $5-\mathrm{HT} 1 \mathrm{~B}$ agonist; third, 5-HT has no effect in 5-HT1B receptor knock-out mice. Our results show that in the developing barrel field of the neonatal mice, 5-HT1B receptors mediate an activitydependent regulation of the TC EPSC that could favor the propagation of high-frequency TC activity.

Key words: primary somatosensory cortex; barrel field; 5hydroxytryptamine; serotonin; CP93129; 5-HT1B receptor; 5-HT1D receptor
In the primary somatosensory $(\mathrm{S} 1)$ cortex of the rodent, the barrel field is a characteristic topographic projection of the peripheral sensory receptors. Sensory inputs from each mystacial vibrissa converge to a restricted zone in the cortical layer IV called a barrel, and the barrels form an ordered map that is a point to point representation of the contralateral mystacial pad (Woolsey and Van der Loos, 1970; Welker, 1971; Armstrong-James and Fox, 1987). The development of the barrel field requires a signal from the whiskers during a critical period (Van der Loos and Woolsey, 1973; Woolsey and Wann, 1976), but the nature of this signal is unknown. In particular, the relative contributions of trophic factors and neuronal activity is still disputed. The genetic inactivation of NMDA receptors (Iwasato et al., 1997) prevents the barrel field formation, indicating that glutamatergic transmis-

Received July 23, 2001; revised Sept. 24, 2001; accepted Oct. 3, 2001.

This work was supported by the Association Franco-Israélienne pour la Recherche Scientifique et Technique (Grant 970MAEN07 to N.R. and P.G.), by the Fondation pour la Recherche Médicale (Grants 20000407042/2 and EXC20000915023 to N.R.), and by the Ministère de la Recherche (ACI Biologie du Développement et Physiopathologie, number 141 to N.R. and P.G.). Experiments were initiated at the Institut Alfred Fessard, Centre National de la Recherche Scientifique Unité Propre de Recherche 2212 (Gif sur Yvette, France). We thank René Hen for the gift of the 5-HT1B receptor knock-out mice, Isabelle Seif for transferring the gene knock-out to a $\mathrm{C} 3 \mathrm{H}$ background, and Chantal Alvarez for help with the in situ hybridization. We also thank Etienne Audinat and Serge Charpak for useful discussions, Gérard Sadoc for programming, Sophie Juszczak-Haguenin and Mohamed Hanafi for technical support, and Pfizer for the gift of CP93129.

Correspondence should be addressed to Dr. Nicole Ropert, Institut National de la Santé et de la Recherche Médicale EPI-0002, Laboratoire de Neurophysiologie et Nouvelles Microscopies, Ecole Supérieure de Physique et de Chimie Industrielle, 10 rue Vauquelin, Paris 75231 cedex 5, France. E-mail: nicole.ropert@espci.fr.

Copyright (C) 2002 Society for Neuroscience $0270-6474 / 02 / 220886-15 \$ 15.00 / 0$ sion is a key signal, but trophic actions seem also critical: normal barrels can form after blockade of activity in the infraorbital nerve (Henderson et al., 1992) and in S1 cortex (Chiaia et al., 1992; Schlaggar et al., 1993); the remodeling of the barrel field induced by a peripheral lesion is maintained after blockade of activity in S1 cortex (Chiaia et al., 1994), and the thalamocortical (TC) axons segregate in S1 cortex after selective cortical NMDA receptor inactivation (Iwasato et al., 2000).

The importance of 5-HT for the barrel field development was first suggested by the observation of a transient serotonergic hyperinnervation of the barrels in neonate rodents (Fujimiya et al., 1986; D'Amato et al., 1987) and confirmed in monoamine oxidase A (MAOA) knock-out mice in which excessive 5-HT levels during the neonatal period prevent the formation of barrels (Cases et al., 1996; Vitalis et al., 1998). A rescue of the barrel phenotype is observed in the MAOA knock-out mice by the inactivation of the 5-HT1B receptor gene (Salichon et al., 2001). These results show the importance of 5-HT1B receptors that are transiently expressed by the TC terminals (Leslie et al., 1992; Bennett-Clarke et al., 1993), but it is unclear how 5-HT and the 5-HT1B receptors influence the formation of barrels. A trophic action has been suggested because the depletion of 5-HT in neonates causes an activity-independent reduction of barrel size (Rhoades et al., 1998), and 5-HT1B receptor activation increases thalamic axonal growth in vitro (Lieske et al., 1999; Lotto et al., 1999). Neuronal activity may also play an important role: in neonates, the 5-HT1B receptor activation inhibits polysynaptic TC responses in S1 cortex (Rhoades et al., 1994). Finally thalamic neurons express the 5-HT plasmic transporter 5-HTT (Bennett- 
Clarke et al., 1996), and the type 2 vesicular monoamine transporter VMAT2 (Lebrand et al., 1996; 1998), therefore TC axons could use 5-HT as a cotransmitter of glutamate.

To test the hypothesis of an activity-dependent effect of 5-HT on the barrel development, we have studied the effect of 5-HT on the monosynaptic TC EPSC in TC slice preparation of the neonate mice.

Preliminary results have been presented in abstract form (Lebrand et al., 1998a; Laurent et al., 1999).

\section{MATERIALS AND METHODS}

Thalamocortical slice preparation. Slices were prepared from wild-type $\mathrm{C} 3 \mathrm{H}$ and 129SV mice and from 5-HT1B receptor knock-out mice with a 129SV genetic background (Saudou et al., 1994), and a C3H background was back-crossed for 10 generations. In early experiments, the animals were raised locally. Later gravid females were obtained mostly from Iffa Credo (L'Arbresle, France) and sometimes from Janvier (Le Genest Saint Isle, France), and the mice were born in the local animal house. The day of birth was counted as postnatal day $0(\mathrm{P} 0)$. Most experiments were done with neonate mice (P7 $\pm 1 \mathrm{~d} ; n=124$; range, $\mathrm{P} 5-\mathrm{P} 9)$. Some controls were done with older mice (P23 \pm 4 d; $n=22$; range, P18-P29). The animals were anesthetized by intraperitoneal injection of pentobarbital $(15 \mathrm{mg} / \mathrm{kg})$ and decapitated. The brain was rapidly removed and placed in oxygenated $\left(5 \% \mathrm{CO}_{2}, 95 \% \mathrm{O}_{2}\right)$ cold artificial CSF (ACSF). The TC slices were cut ( $300 \mu \mathrm{m}$ thickness) with a vibratome (DSK DTK-1000 or VT1000S; Leica, Nussloch, Germany) as previously described (Agmon and Connors, 1991). The slices were maintained $1 \mathrm{hr}$ at $34^{\circ} \mathrm{C}$ and later at room temperature $\left(25^{\circ} \mathrm{C}\right)$ in oxygenated standard ACSF with 5-10 mm lactate (Izumi et al., 1994).

Electrophysiological recordings and data analysis. The slices were placed in a small recording chamber $(1 \mathrm{ml})$, maintained by a platinum grid, and submerged in a constant $(2 \mathrm{ml} / \mathrm{min})$ ACSF perfusion at $25^{\circ} \mathrm{C}$. Renewal of the medium was achieved within 1 min as shown by the bath application of $\mathrm{GABA}_{\mathrm{A}}$, AMPA-kainate (KA), or NMDA antagonists that induced a maximal effect within $1 \mathrm{~min}$. The $\mathrm{S} 1$ cortex and the layer IV neurons were recognized in the recording conditions by visualization of the large dorsal barrels (Fig. 1) using an upright fixed stage microscope (Axioskop FS; Zeiss, Oberkochen, Germany) with Nomarski optics and an infrared video camera (Newvicon C2400; Hamamatsu, Shizouka, Japan). Stainless steel bipolar semimicroelectrodes $(100 \mu \mathrm{m}$ tip diameter, $250 \mu \mathrm{m}$ intertip distance; Rhodes Medical Instruments) were placed in the internal capsule (IC) near the thalamic border to activate the TC axons. The frequency of the IC stimulation to obtain stable responses was 0.07 Hz. The intensity of the stimulation was adjusted to evoke a unitary TC EPSC (Fig. 2). Whole-cell voltage- and current-clamp recordings were obtained with Axopatch 1D or 200A amplifiers (Axon Instruments, Foster City, CA) from the soma of S1 cortical neurons (Stuart et al., 1993). Recording pipettes were pulled from cleaned borosilicate glass tubes and coated with beeswax. The tip resistance was 4-6 M $\Omega$. During recording, the series resistance $\left(R_{\mathrm{s}}\right)$ was not compensated and was monitored continuously by applying short $(20 \mathrm{msec})$ negative voltage steps $(-1$ to $-3 \mathrm{mV})$ before each IC stimulation $\left(R_{\mathrm{s}}=23 \pm 7 \mathrm{M} \Omega ; n=\right.$ 94). Recordings were discarded if the $R_{\mathrm{s}}$ increased $>20 \%$. The voltage and current signals were filtered $(5 \mathrm{kHz})$, digitized $(10 \mathrm{kHz})$, and stored directly on the computer by a Labmaster TL-1 DMA acquisition board (Axon Instruments). The data were analyzed using programmable software (Acquis1; Biologic, Claix, France). The latency of the response was obtained by measuring the time between the beginning of the stimulation artifact and a threshold value of the first derivative of the response. The amplitude of the TC EPSC was measured between the baseline and the peak of the response; the baseline was obtained by averaging the signal for 1 or 2 msec between the stimulation artifact and the onset of the response; the peak of the response was measured by detection of the maximal absolute value and averaging 5 or 7 data points around this value. The time constant of decay of the EPSC was obtained by fitting the decay of the response with a double exponential function. In some cases, a single time constant $\tau$ was found. When the decay was biexponential, an estimation of the duration of the responses was obtained by calculating a weighted time constant $\tau_{=} \tau_{1} \times[A 1 \div(A 1+A 2)]+\tau_{2} \times[A 2 \div(A 1+$ $A 2)], \tau_{1}$ and $\tau_{2}$ being the fast and the slow time constants respectively, and $A 1$ and $A 2$ the amplitude of the fast and slow components, respectively. To quantify the responses to 5-HT and to the 5-HT1B agonist CP93129, the relative amplitude of the TC EPSCs was calculated by normalization of the individual values to the mean value obtained before drug application. The maximal effect of the drug was estimated by calculating the running average $(n=10)$ of the relative amplitude of the TC EPSC and taking the minimum reached by the running averaged at the end of the drug application. Summary data were obtained by averaging the relative amplitude of the individual TC EPSCs obtained from several cells in the same experimental conditions. Paired pulse and trains of high-frequency IC stimulation were used to assess the short-term changes of the TC EPSC; the interval between the stimuli was $20 \mathrm{msec}$, and five stimuli were applied in a train; we measured the amplitude of the AMPA component of the EPSC recorded at $-80 \mathrm{mV}$. The short-term change induced by the paired pulse IC stimulation was quantified by the paired pulse ratio (PPR) equal the amplitude ratio of the second response to the first response $\left(a_{2} / a_{1}\right)$. The short-term changes induced by the high-frequency trains of IC stimulation were quantified by estimation of the relative EPSC amplitude $\left(R_{2}\right.$ to $\left.R_{5}\right)$ calculated as the amplitude ratio of the second to the fifth EPSCs to the first EPSC $\left(R_{2}=a_{2} / a_{1} ; R_{3}=a_{3} / a_{1} ; R_{4}=\right.$ $\left.a_{4} / a_{1} ; R_{5}=a_{5} / a_{1}\right)$. Results are given as mean $\pm \mathrm{SD}$ for statistical analysis, and mean \pm SEM for graphical representations of the summary data. The variability of the response latency was estimated by the coefficient of variation $\mathrm{CV}=\mathrm{SD} \div$ mean. The significance levels were calculated using paired or unpaired Student's two-tailed $t$ test.

In the neonate mice, we confirmed that a minimal IC stimulation evoked a TC EPSC without disynaptic IPSCs, as shown by the absence of a delayed outward postsynaptic response at $0 \mathrm{mV}$. In older mice, a disynaptic $\mathrm{GABA}_{\mathrm{A}}$ mediated IPSC was evoked by IC stimulation. The IPSC was identified by a longer and more variable latency than the EPSC and by a reversal potential near the chloride equilibrium $(-40 \mathrm{mV}$ in our recording conditions). To block the disynaptic IPSC, a $\mathrm{GABA}_{\mathrm{A}}$ antagonist (10 $\mu \mathrm{M}$ BIC or $100 \mu \mathrm{M}$ PTX) was added to the standard ACSF. In this condition, it was necessary to add AMPA-KA or NMDA antagonist (in $\mu \mathrm{M}$ : $10 \mathrm{CNQX}, 50 \mathrm{D}-\mathrm{AP}-5$, or $100 \mathrm{D}, \mathrm{L}-\mathrm{AP}-5)$ to reduce the spontaneous synchronized discharges (Gutnick et al., 1982), and to record in isolation either the NMDA or the AMPA component of the TC EPSC.

Solutions and pharmacological compounds. The external standard ACSF contained (in mM): $\mathrm{NaCl} 126, \mathrm{KCl} 1.5, \mathrm{KH}_{2} \mathrm{PO}_{4} 1.25, \mathrm{MgSO}_{4}$ $1.5, \mathrm{CaCl}_{2} 2, \mathrm{NaHCO}_{3} 26$, and glucose 10; osmotic pressure, $298 \pm 3$ mOsm. The following drugs were applied in the perfusion: 5-hydroxytryptamine $(5-\mathrm{HT})$ creatinine sulfate $(0.5-20 \mu \mathrm{M}$; Sigma, St. Louis, MO); D,L-2-amino-5-phosphonopentanoic acid (D,L-AP-5) (100 $\mu \mathrm{M}$; Tocris Cookson, Ballwin, MO); D-AP-5 (50 $\mu \mathrm{M}$; Tocris); 6-cyano7-nitroquinoxaline-2,3-dione (CNQX) (10 $\mu \mathrm{M}$; Tocris); picrotoxin (PTX) $(100 \mu \mathrm{M}$; Research Biochemicals, Natick, MA); bicuculline metochloride (BIC) (10 $\mu \mathrm{M}$; Sigma); 1,4-dihydro-3-(1,2,3,6-tetrahydro4-pyridinyl)-5H-pyrolo[3,2-b]pyridin-5-one (CP93129 dihydrochloride) (100 nM; a gift from Pfizer, Groton, CT). The pipette solution contained (in $\mathrm{mM}$ ): (1) for whole-cell voltage-clamp recordings, $\mathrm{Cs}$ gluconate $120, \mathrm{CsCl} 10, \mathrm{~K}$-ATP $4, \mathrm{MgCl}_{2}$ 2, HEPES 10, Na-GTP 0.4, $\operatorname{EGTA}(\mathrm{CsOH}) 0.2, \mathrm{pH} 7.35$, adjusted with $\mathrm{CsOH}$; osmotic pressure, $273 \pm 2 \mathrm{mOsm}$. (2) For whole-cell current-clamp recordings, $\mathrm{K}$ gluconate 144, $\mathrm{MgCl}_{2}$ 3, HEPES 10, EGTA(KOH) 0.2, $\mathrm{Na}_{2}$-ATP 2, Na-GTP 0.2 , pH 7.35, adjusted with KOH. The potentials were corrected for the liquid junction potential $(-10 \mathrm{mV})$. For extracellular field recordings, we used large $(1-2 \mathrm{M} \Omega$ ) patch pipettes that were filled with ACSF.

In situ hybridization. Swiss OF1 and $\mathrm{C} 3 \mathrm{H}$ mice from Iffa Credo were analyzed at P0, P7, P10, P15, and as adults. Fresh frozen sections $(15 \mu \mathrm{m})$ were cut serially in the coronal plane. Alternate sections were used for Nissl staining and for in situ hybridization of the 5-HT1B and 5-HT1D receptors. cDNA fragments of the 5-HT1B and 5-HT1D receptor genes (kind gift of Luc Marotaux CNRS, Strasbourg, France), containing the full-length coding sequence, were subcloned in pBluescript KS vectors (Stratagene, La Jolla, CA). 5-HT1B and 5-HT1D receptor plasmids were linearized with EcoRI (Roche Diagnostics) for antisense RNA synthesis and with $X b a \mathrm{I}$ (Roche Diagnostics) for sense synthesis. The in vitro transcription was performed using the Promega (Madison, WI) kit, and probes were labeled with ${ }^{35} \mathrm{~S}-\mathrm{UTP}(>1000 \mathrm{Ci} / \mathrm{mmol}$; Amersham, Arlington Heights, IL). Tissue sections were post-fixed for $15 \mathrm{~min}$ in $4 \%$ paraformaldehyde, washed in PBS, acetylated, dehydrated, air-dried, and hybridized with $10^{6} \mathrm{cpm}$ overnight in a humid chamber at $50^{\circ} \mathrm{C}$. Sections were sequentially treated $30 \mathrm{~min}$ at $42^{\circ} \mathrm{C}$ in $5 \times$ SSC, $0.1 \%$ dithiothreitol (DTT); $20 \mathrm{~min}$ at $60^{\circ} \mathrm{C}$ in $2 \times \mathrm{SSC}, 50 \%$ formamide, $0.5 \%$ DTT; $30 \mathrm{~min}$ at $37^{\circ} \mathrm{C}$ in RNase buffer $(23 \% \mathrm{NaCl}, 10 \mathrm{~mm}$ Tris, 5 mM EDTA) containing $0.02 \%$ RNase A (Roche Diagnostics); $15 \mathrm{~min}$ at $37^{\circ} \mathrm{C}$ in RNase buffer; $15 \mathrm{~min}$ at $37^{\circ} \mathrm{C}$ in $2 \times \mathrm{SSC}$; and $15 \mathrm{~min}$ at $37^{\circ} \mathrm{C}$ in $0.1 \times \mathrm{SSC}$. The 


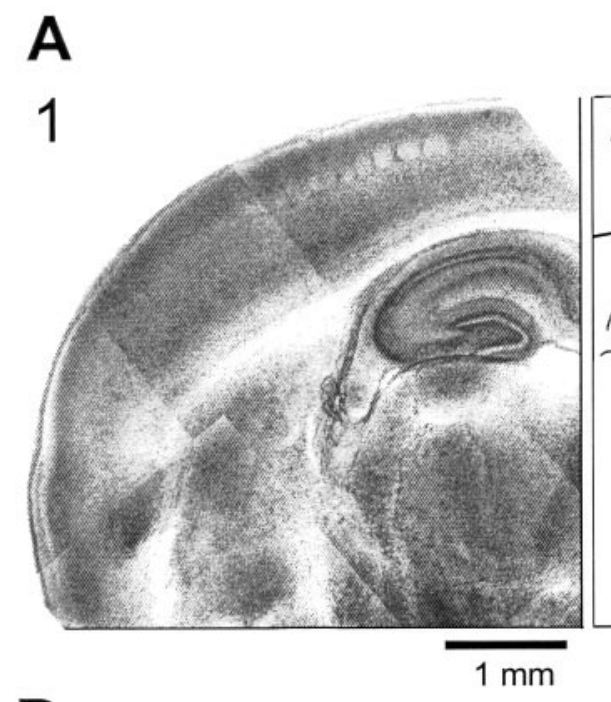

Figure 1. TC slice preparation and identification by infrared videomicroscopy and spike discharge of layer IV neurons in the primary somatosensory $(S 1)$ cortex of the neonate mouse. $A$, The TC slice preparation of a P5 mouse is visualized at a low magnification by infrared videomicroscopy in recording conditions (1) and schematized for structure identification (2). The S1 cortex with six layers (I-VI) is recognized by the presence of barrels in layer IV. The larger barrels of the PMBSF are located dorsally to hippocampal regions [Ammon's horn: CA1, and CA3 and fascia dentata (FD)]. A bipolar stimulating electrode (Stim) is placed in the internal capsule (IC) to activate the TC axons originating in the ventrobasal $(V B)$ thalamic nucleus and projecting through the nucleus reticularis $(R e)$ to layer IV in S1 cortex. The recording electrode (Rec) is located over a PMBSF barrel. $B$, View of S1 cortex at an intermediate magnification with the tip of the recording pipette over a large PMBSF barrel in layer IV. $C$, View at a higher magnification of a layer IV neuron with a nonpyramidal soma and no apical dendrite. Pial orientation is identical in $B$ and $C . D, E$, Current-clamp recordings of the spike discharge evoked by current injection in a fast-spiking $(D)$ and a regular-spiking $(E)$ layer IV neuron. The bottom traces illustrate the current steps that were injected for $1 \mathrm{sec}$. The fast-spiking neuron exhibits a maintained spike frequency. The so-called regular-spiking neuron shows a strong spike adaptation.
B

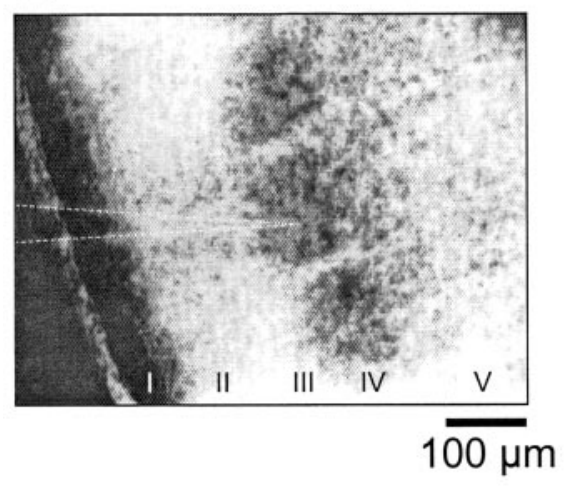

C
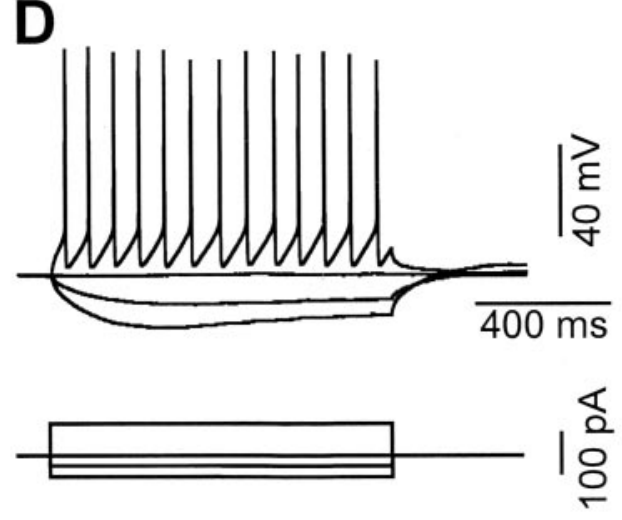

$\mathbf{E}$
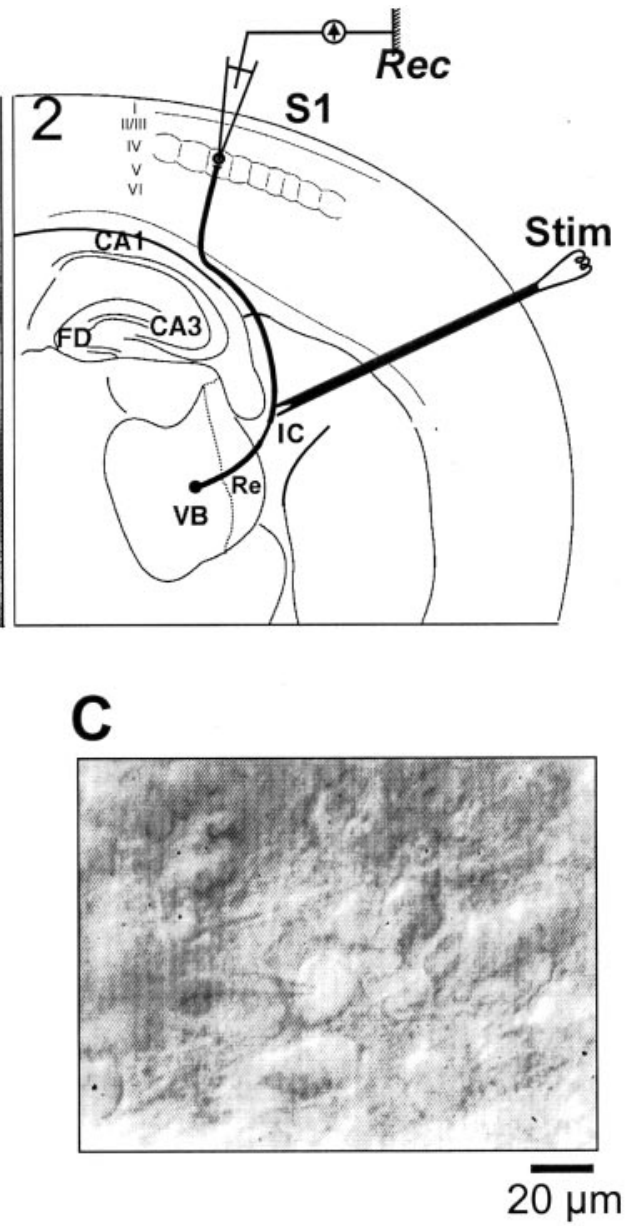

slides were dehydrated, air-dried, dipped in photographic emulsion (NTB2; Eastman Kodak, Rochester, NY), and exposed for $\sim 10$ d. After development of the emulsion, the sections were counterstained with cresyl violet.

\section{RESULTS}

\section{Characterization of the monosynaptic TC EPSC}

Experiments were done in neonate mice (P5-P9) with two different genetic backgrounds $(\mathrm{C} 3 \mathrm{H}$ and $129 \mathrm{SV})$. The results were similar in both backgrounds and were pooled. The recordings were made in S1 cortex identified by the presence of barrels visualized by infrared videomicroscopy in the recording conditions (Agmon and Connors, 1991; Fleidervish et al., 1998; Feldmeyer et al.,1999). The recordings were limited to the soma of the layer IV neurons in the large barrels of the posteromedial barrel subfield (PMBSF) that correspond to the vibrissae of the posterior mystacial pad, and they were restricted to neurons with a nonpyramidal soma (Fig. 1). In preliminary experiments, we characterized the neurons in the layer IV using current-clamp recordings and potassium as the main cation of the pipette solution (see Materials and Methods). The neurons $(n=34)$ were identified by their spike discharge in response to current injection (McCormick et al., 1985; McCormick and Prince, 1987; ChagnacAmitai and Connors, 1989; Feldmeyer et al., 1999; Lubke et al., 2000). Most neurons $(n=29)$ displayed long-duration spike $(2.18 \pm 0.46 \mathrm{msec})$, small afterhyperpolarization (AHP) $(12 \pm 5$ $\mathrm{mV})$, and strong spike adaptation, typical of the regular spiking 


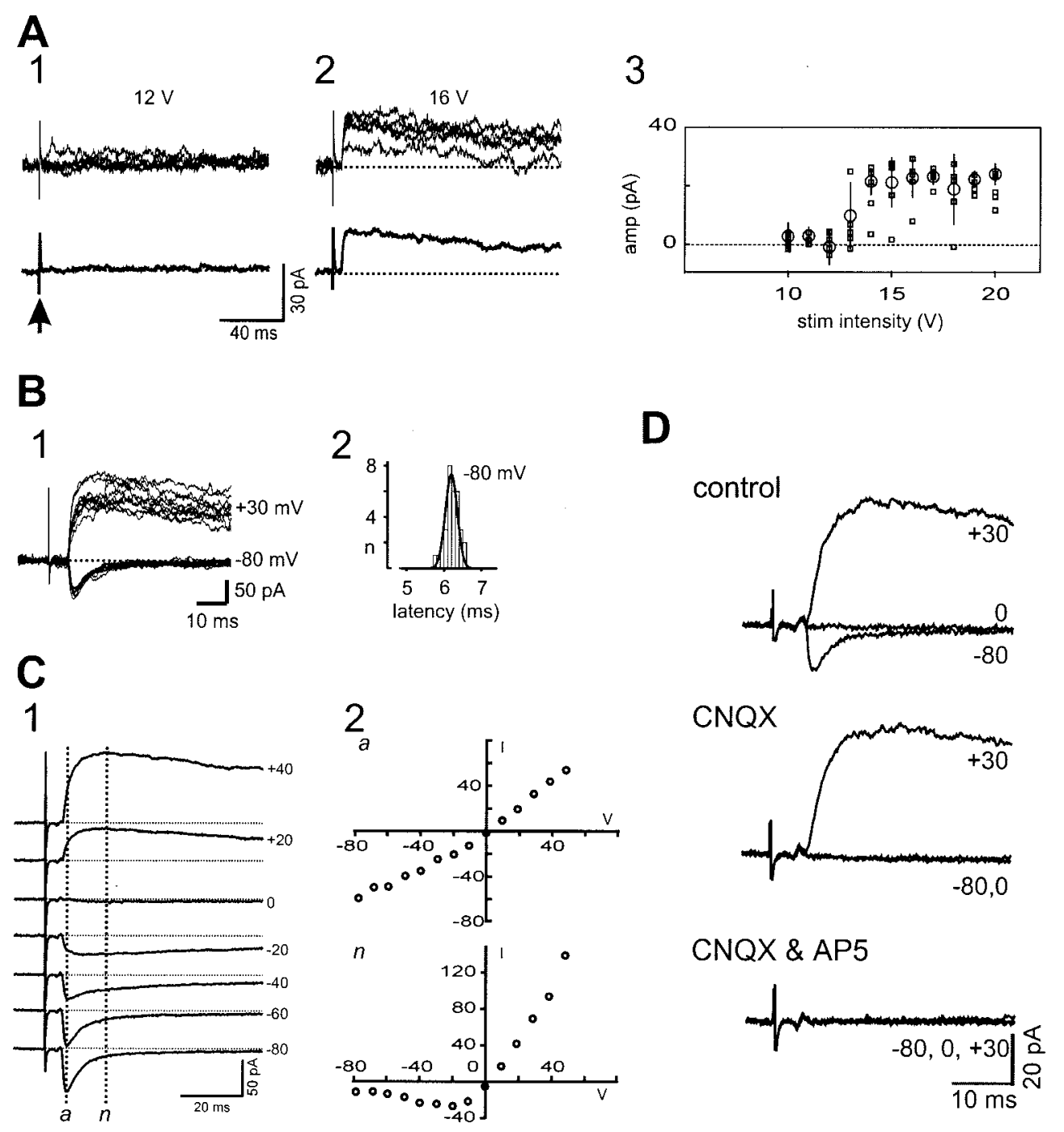

Figure 2. Identification of the AMPA$\mathrm{KA}$ and NMDA components of the monosynaptic TC EPSC recorded in layer IV S1 cortex of P6-P8 wild-type mice. The IC is stimulated at $0.07 \mathrm{~Hz}$. $A$, A minimal IC stimulation evoked a unitary TC EPSC at $+30 \mathrm{mV}$ holding potential. The IC stimulation intensity was changed from 10 to $20 \mathrm{~V}$ at intervals of $1 \mathrm{~V}$ to find the intensity that evokes unitary responses. 1, 2, Five individual (top traces) and averaged (bottom traces) TC EPSCs evoked by a subthreshold $(1,12 \mathrm{~V})$ and a minimal $(2,16 \mathrm{~V})$ intensity. 3 , In the same cell, the individual (squares), mean (circles, $n=5$ ), and SD of the peak amplitude of the TC EPSCs are plotted against stimulation intensity. From 10 to $12 \mathrm{~V}$, responses fluctuate around baseline $(1.65 \pm 5.38 \mathrm{pA} ; n=15)$. At $13 \mathrm{~V}$, responses were seen, and the failure rate was high (four of five). From 14 to $20 \mathrm{~V}$, the failure rate was reduced (3 of 35), and the amplitude of the TC EPSCs fluctuate around a constant plateau value $(23.4 \pm 4.9 \mathrm{pA} ; n=32)$, as expected for a unitary EPSC. $B$, The IC stimulation evoked a monosynaptic EPSC. 1, Superimposition of 10 individual TC EPSCs at -80 and $+30 \mathrm{mV}$. The latency of the response was identical at both potentials and showed little variability. 2, In the same cell, the response latency measured at $-80 \mathrm{mV}$ was $6.28 \pm$ $0.18 \operatorname{msec}(n=30)$ and followed a Gaussian distribution as expected for a monosynaptic response. $C, I-V$ curves of the early and late components of the TC EPSC. 1 , Averaged $(n=10)$ TC EPSCs at several holding potentials $(V)$ between -80 and $+40 \mathrm{mV}$ with a reversal potential near $0 \mathrm{mV}$. The kinetics of the TC EPSCs was changed with voltage, being faster at $-80 \mathrm{mV}$ than at more positive potentials. The amplitude of the

TC EPSCs was measured at the peak of the early response at $-80 \mathrm{mV}(a)$ and at the peak of the late response at $+40 \mathrm{mV}(n)$. 2, The $I-V$ curve of the early component $(a)$ was almost linear with a reversal at $-0.43 \mathrm{mV}$. The $I-V$ curve of the late component $(n)$ reversed at $-4 \mathrm{mV}$. $D$, Effect of CNQX and AP-5 on the TC EPSCs. Averaged $(n=5)$ TC EPSCs at $+30,0$, and $-80 \mathrm{mV}$ in control, in $10 \mu \mathrm{M}$ CNQX, and in $10 \mu \mathrm{M}$ CNQX plus $100 \mu \mathrm{M}$ D,L-AP-5. The fast and the slow inward currents seen at $-80 \mathrm{mV}$ in standard ACSF were blocked by the AMPA-KA antagonist CNQX. The peak amplitude of the outward response at $+30 \mathrm{mV}$ was unchanged in CNQX and blocked by the NMDA antagonist AP-5. A small triphasic residual response is seen in CNQX plus AP-5: it precedes the TC EPSC, and it is insensitive to the holding potential and corresponds most likely to the presynaptic TC fiber activity.

neurons (Fig. $1 E$ ), indicating that they are probably spiny glutamatergic stellate neurons. The remaining neurons $(n=5)$ displayed significant $(p<0.01)$ shorter duration spikes $(1.54 \pm 0.16$ msec), larger AHP $(19 \pm 2 \mathrm{mV})$, and weak spike adaptation typical of the fast spiking GABAergic neurons (Fig. 1D). In the subsequent voltage-clamp recordings it was necessary to use cesium in the pipette solution to record synaptic responses at potentials more positive than $-70 \mathrm{mV}$. These conditions do not allow the identification of neurons from their spike discharge. However, based on our preliminary experiments, voltage-clamp recordings were probably obtained from a heterogeneous population of layer IV neurons with a majority of spiny stellate neurons and a minority of GABAergic neurons. In all the neurons that we recorded in the layer IV, we found that the IC-evoked EPSCs were sensitive to 5-HT, therefore the data from all neurons were pooled.

The low-frequency stimulation $(0.07 \mathrm{~Hz})$ of the IC evoked stable postsynaptic current responses in layer IV neurons (Fig. 2). When the intensity of the IC stimulation was increased above the threshold, the amplitude of the responses fluctuated around a constant value (Fig. $2 A$ ) that corresponds to a unitary response caused by the release of glutamate by a single presynaptic axon (Stern et al., 1992). As an attempt to detect a possible input specific effect of 5-HT, the intensity of the IC stimulation was chosen to evoke a unitary response. The latency of the response was relatively long $(6.09 \pm 1.14 \mathrm{msec} ; n=106)$, as expected for neonate mice with partially myelinated axons (Jacobson, 1963). The latency distribution calculated for individual cells could be fitted with a single Gaussian with weak variability $(\mathrm{CV}=0.06 \pm$ $0.04 ; n=50)$, indicating that the IC-evoked responses were monosynaptic (Fig. 2B). In adult rats, the layer VI pyramidal neurons of S1 cortex project through the IC to the thalamus (Bourassa et al., 1995) and send axon collaterals to layer IV (Zhang and Deschenes, 1997). Therefore, the IC stimulation may 


\begin{tabular}{|c|c|c|c|}
\hline Mouse phenotype & Wild type & Wild type & $\begin{array}{l}\text { 5-HT1B receptor } \\
\text { knock-out }\end{array}$ \\
\hline Age & $7 \pm 1 \mathrm{~d}(124)$ & $23 \pm 4 \mathrm{~d}(22)$ & $7 \pm 1 \mathrm{~d}(13)$ \\
\hline EPSC latency & $6.09 \pm 1.14 \mathrm{msec}(106)^{* * *}$ & $2.79 \pm 0.70 \mathrm{msec}(22)^{* * *}$ & $6.49 \pm 1.16 \mathrm{~ms}(13)$ \\
\hline Latency CV & $0.06 \pm 0.04(50)$ & $0.03 \pm 0.02(7)$ & nd \\
\hline EPSC amplitude at $-80 \mathrm{mV}$ & $51 \pm 32 \mathrm{pA}(104)^{*}$ & $93 \pm 119 \mathrm{pA}(22)^{*}$ & $54 \pm 40 \mathrm{pA}(13)$ \\
\hline EPSC decay at $-80 \mathrm{mV}$ & $14 \pm 13 \mathrm{msec}(42)^{* * *}$ & nd & nd \\
\hline EPSC decay at $+30 \mathrm{mV}$ & $163 \pm 44 \operatorname{msec}(39)^{* * *}$ & nd & nd \\
\hline NMDA/AMPA ratio & $1.64 \pm 1.23(82)$ & nd & $0.86 \pm 0.18(6)$ \\
\hline PPR & $0.71 \pm 0.27(26)$ & $0.51 \pm 0.08(3)$ & $0.74 \pm 0.36(4)$ \\
\hline
\end{tabular}

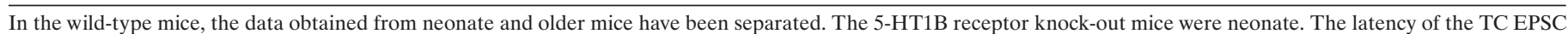

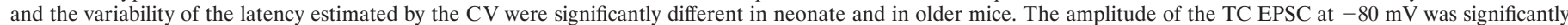

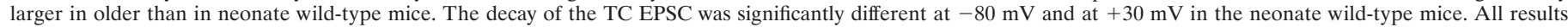
are given as mean $\pm \mathrm{SD}(n)$. The asterisks indicate the significance level calculated using the $t$ test $\left({ }^{* * *} p<0.0001 ;{ }^{*} p<0.01\right)$. nd, Not determined.

activate the corticothalamic (CT) pathway, giving rise to antidromic spikes in the layer VI pyramidal neurons, and evoking a monosynaptic response in layer IV (Agmon and Connors, 1991). To identify the pathway that gives rise to the monosynaptic responses in layer IV in our TC slice preparation, we tested the ability of the IC stimulation to evoke an antidromic action potential in the layer VI pyramidal neurons. In seven TC slices, the threshold of monosynaptic unitary responses in layer IV neurons was first measured in response to IC stimulation (Fig. $2 A$ ). In the same slices, layer VI pyramidal neurons of the same cortical column were recorded in the current-clamp mode and identified by their morphological aspect in infrared videomicroscopy and by their regular spike discharge. After the IC stimulation, a monosynaptic EPSP was recorded in several cells $(n=7)$, but no antidromic spike discharge was seen in layer VI pyramidal neurons $(n=16)$ even when the IC stimulation intensity was increased up to 10 times that necessary to evoke a unitary EPSC in layer IV. We also used extracellular field recordings to further characterize the layer IV cortical responses evoked by IC stimulation. As reported before (Agmon and Connors, 1991), the layer IV intracellular monosynaptic EPSCs were correlated with an extracellular slow negativity preceded by an extracellular fast negativity caused by the TC fiber spike discharge (data not shown). In the infragranular layers V/VI of the same slices, we did not record an extracellular fast negativity caused by antidromic spike discharge of pyramidal neurons and preceding the layer IV EPSC. These results indicate that the probability to evoke an antidromic spike discharge in the layers V/VI pyramidal neurons is probably very weak in our TC slice preparation and that the layer IV monosynaptic EPSCs evoked by IC stimulation are more likely attributable to the activation of the ascending TC axons.

The monosynaptic TC responses to IC stimulation were further identified by their physiological and pharmacological properties (Fig. 2). The kinetics of the TC responses was sensitive to the membrane potential being faster at $-80 \mathrm{mV}$ and slower at potentials more positive than $-60 \mathrm{mV}$ (Table 1). The decay of the TC responses at $-80 \mathrm{mV}$ could be fitted with a two exponential function $\left(\tau_{1}=4 \pm 1 \mathrm{msec}, 90 \pm 5 \%\right.$; $\left.\tau_{2} 109 \pm 98 \mathrm{msec}\right)$ with a weighted time constant of $14 \pm 13 \mathrm{msec}(n=42)$ (see Materials and Methods). Similar fast and slow values were obtained for the AMPA, the kainate (KA) (Kidd and Isaac, 1999), and the NMDA components of the TC EPSC (Barth and Malenka, 2001). As reported before (Barth and Malenka, 2001), the decay of the TC responses at $+30 \mathrm{mV}$ was fitted either with a single or with a two exponential function with a time constant of $175 \pm 33 \mathrm{msec}$ $(n=13)$ significantly different from the decay at $-80 \mathrm{mV}(p<$ $0.001)$. The reversal potential of the TC responses was near $0 \mathrm{mV}$ and corresponds to the reversal potential of the NMDA and AMPA-kainate responses in our recording conditions. The early component of the TC EPSC was blocked by CNQX, an AMPAkainate receptor antagonist $(n=3)$ (Fig. 2D) and its currentvoltage $(I-V)$ curve (measured at the peak of the response at -80 $\mathrm{mV}$ ) was linear (Fig. 2C2a), as reported for AMPA receptors that do not express polyamine block (Ozawa et al., 1998). At $-80 \mathrm{mV}$ both the NMDA and the KA receptors appear to contribute to the slow component of the TC EPSC, as shown by the antagonistic effects of AP-5, an NMDA receptor blocker, in a majority of cells ( $n=7$ of 11$)$ and of CNQX in the remaining cells $(n=4$ of 11). As expected from the strong rectification of KA receptors at $+30 \mathrm{mV}$ (Kidd and Isaac, 1999), the NMDA receptors contribute exclusively to the slow component of the TC EPSC that was completely blocked by AP-5 at $+30 \mathrm{mV}(n=13)$. The $I-V$ curve of the slow component of the TC EPSC (measured at the peak of the response at $+30 \mathrm{mV}$ ) expressed an inward rectification with a maximum near $-30 \mathrm{mV}$ (Fig. $2 C 2 n$ ) reminiscent of the NMDA receptor $I-V$ curve. These results confirm that the activation of the TC axons by the IC stimulation activates the AMPA-KA and the NMDA glutamate receptors (Agmon and O'Dowd, 1992; Kidd and Isaac, 1999). The relative contribution of the NMDA component was estimated by calculating the ratio of the peak amplitude of the responses at +30 and at $-80 \mathrm{mV}$. Confirming previous results (Crair and Malenka, 1995), we found a major contribution of the NMDA component in neonate mice $($ NMDA-AMPA ratio $=1.64 \pm 1.23 ; n=82)$. In CNQX and AP-5, the TC EPSC was completely blocked, indicating that, in our conditions, there was no contribution of a serotonergic postsynaptic response to the EPSC (Roerig et al., 1997). In several experiments $(n=21)$, we recorded a small triphasic response that preceded the EPSC (Fig. 2D). This response was probably caused by the TC afferent fiber discharge: it had a lower threshold than the TC EPSC, it was synchronized with the early fast negative wave of the layer IV extracellular field, and it was voltage-insensitive and followed $50 \mathrm{~Hz}$ stimulation.

In the neonate mice (Fig. 2), we confirmed that the minimal IC stimulation evoked a unitary TC EPSC without disynaptic GABA $_{\text {A }}$-mediated IPSCs (Agmon and O'Dowd, 1992; Barth and Malenka, 2001). In older mice, disynaptic IPSCs were evoked by IC stimulation (see Materials and Methods). Therefore, in the neonatal mice experiments were done in standard ACSF, 
A
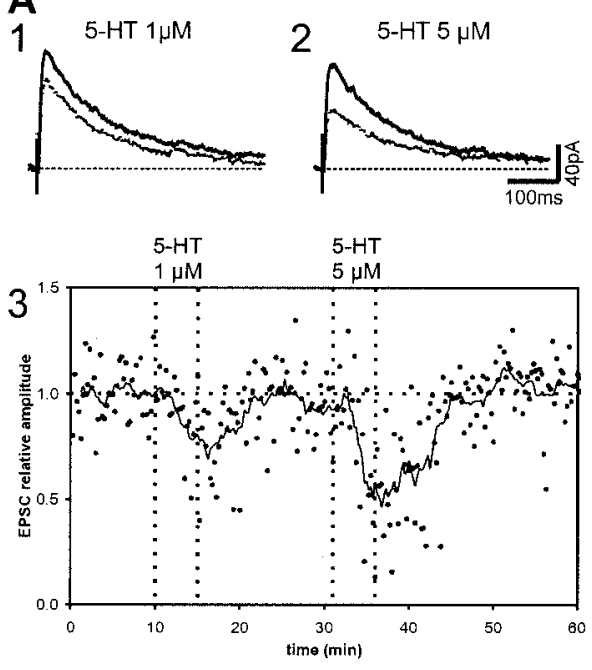

B.

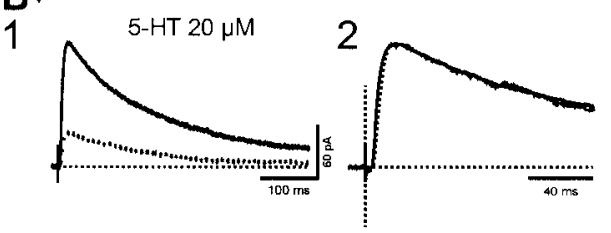

3

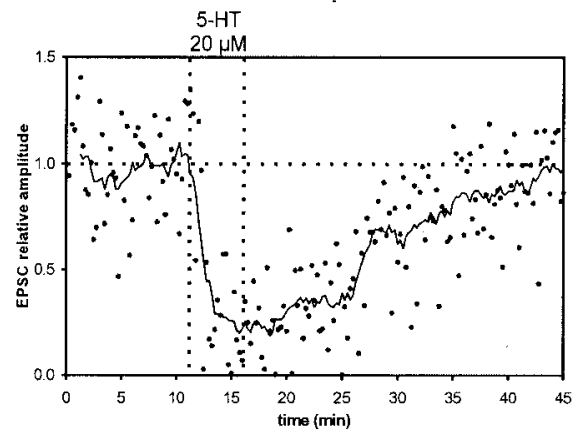

Figure 3. Inhibitory effect of 5-HT on the TC EPSC of neonate wild-type mice. The effect of bath applications of 5-HT at several concentrations has been tested on the NMDA component of the TC EPSC evoked by IC stimulation at $0.07 \mathrm{~Hz}$ in two neurons $(A, B)$ maintained at +30 $\mathrm{mV} . A$, Inhibitory effect of 1 and $5 \mu \mathrm{M}$ 5-HT applied to the same neuron of a P7 mouse. 1, 2, TC EPSCs were averaged $(n=5)$ in control (thick line) and during the response to the successive applications to 5-HT (dotted line) at 1 (1) and 5 $\mu \mathrm{M}$ (2). The applications of 5-HT lasted $5 \mathrm{~min}$, and the second application was made $20 \mathrm{~min}$ after the first. 3, The amplitude of each TC EPSC was normalized to the control value $(107 \pm 14 \mathrm{pA} ; n=$ 40) before the first 5-HT application and plotted against time as individual (dots) and running average ( $n=10$; continuous line). After a $10 \mathrm{~min}$ control period, $1 \mu \mathrm{M}$ 5-HT applied for $5 \mathrm{~min}$ induced a small reduction of the TC EPSC. The minimal relative EPSC at the end of the application $(0.78 \pm 0.22 ; n=10)$ was significantly ( $p<0.0001)$ smaller than the control $(1.00 \pm 0.13 ; n=40)$. After recovery, $5 \mu \mathrm{M} 5$-HT applied for $5 \mathrm{~min}$ induced a larger reduction of the TC EPSC with a minimal relative value $(0.54 \pm 0.24 ; n=$ 10) significantly different from the control $(p<0.0001)$ and from the response at $1 \mu \mathrm{M}(p<0.05)$. $B$, Inhibitory effect of $20 \mu \mathrm{M} 5$-HT on the TC EPSC of another neuron of a P5 mouse. 1, The TC EPSCs were averaged $(n=45)$ in control (thick

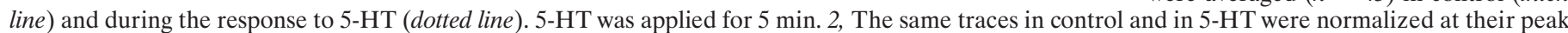

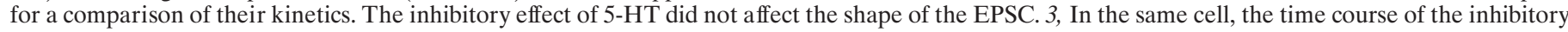

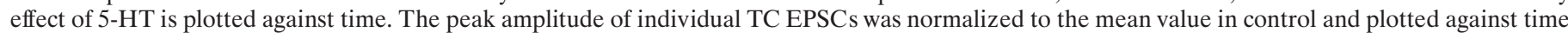

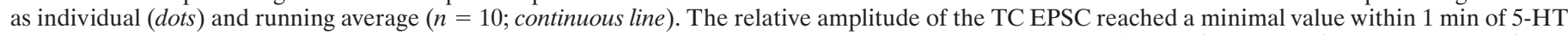

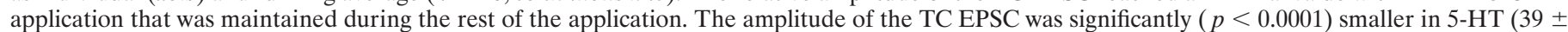

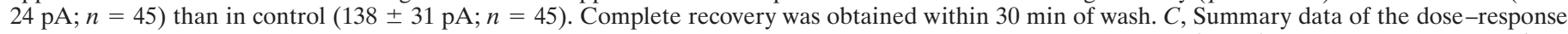

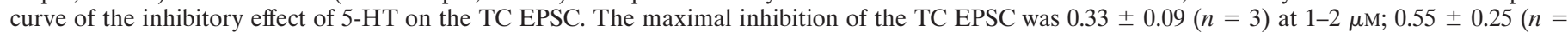
$13)$ at $5 \mu \mathrm{M} ; 0.62 \pm 0.13(n=5)$ at $10 \mu \mathrm{M}$; and $0.74 \pm 0.23(n=6)$ at $20 \mu \mathrm{M}$.

whereas $\mathrm{GABA}_{\mathrm{A}}$ antagonists were needed in older mice to record the EPSC in isolation.

\section{Presynaptic inhibitory effect of 5-HT on the monosynaptic TC EPSC in neonatal mice}

At the beginning of each recording session, the responses at $0 \mathrm{mV}$ were first examined to control the absence of an evoked IPSC (Fig. 2). The effect of 5-HT was then tested on the larger NMDA component of the unitary TC EPSC recorded at $+30 \mathrm{mV}$. After a control period of at least 10 min to establish the stability of the TC EPSC, 5-HT (0.5-20 $\mu \mathrm{M})$ was applied in the bath for $5 \mathrm{~min}$ before returning to standard ACSF. Increasing the duration of the application to $10 \mathrm{~min}$ did not increase the effect of $10 \mu \mathrm{M}$ 5-HT. Therefore, $5 \mathrm{~min}$ applications were used as a standard.

In the neonate mice, the application of 1-20 $\mu \mathrm{M} 5$-HT had no effect on the holding current of the layer IV neurons but induced a significant $(p<0.0001)$ reduction of the peak amplitude of the NMDA component of the TC EPSC (Fig. 3). The inhibitory effect of 5-HT on the TC EPSC was reversible and was enhanced with increased concentrations of 5-HT in the ACSF. We found no significant effect of $0.5 \mu \mathrm{M} 5-\mathrm{HT}$. At higher concentrations, the effect of 5-HT was increased with the concentration (Fig. 3C). We did not attempt to obtain the $\mathrm{IC}_{50}$ of the effect of 5-HT because the widespread expression of the 5-HTT in the neonate and in the older S1 cortex (Lebrand et al., 1998b) limits the diffusion of 5-HT, and one cannot estimate the actual concentration of 5-HT at the receptors in the slice preparation. At relatively high concentrations of 5 -HT $(\geq 10 \mu \mathrm{M})$, we saw an increase of the frequency of spontaneous unitary EPSCs and IPSCs, indicating that 5-HT has several actions in S1 cortex. In the present study, we focused on the effect of 5-HT on TC transmission.

The inhibitory effect of 5-HT on the NMDA component of the TC EPSC could be attributable either to a postsynaptic action of 5-HT on the glutamate receptor responsiveness or to a presynaptic action of 5-HT on the release of glutamate. To evaluate these two possibilities, we compared the effect of 5-HT on the NMDA and the AMPA components of the TC EPSC, and we studied the effect of 5-HT on the paired pulse ratio.

A postsynaptic action of 5-HT is expected to change differentially the NMDA and the AMPA-KA components of the TC EPSC. To demonstrate a possible differential effect of 5-HT on the AMPA-KA and the NMDA components of the TC EPSC we used two strategies: first, we compared the kinetics of the TC EPSC in control and in 5-HT; second we compared the effect of 5-HT on the AMPA-KA and on the NMDA components of the TC EPSC.

The kinetics of the TC EPSC was first estimated visually by 

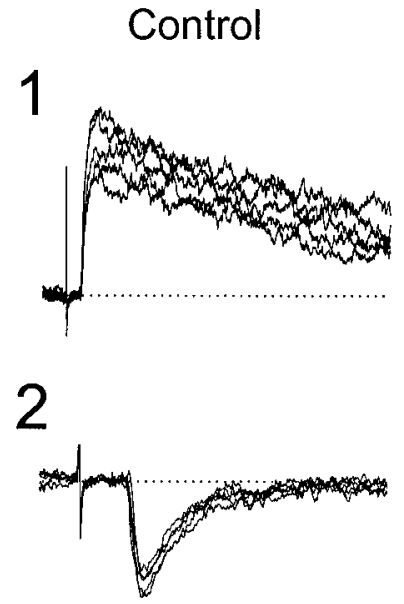

Figure 4. Comparison of the inhibitory effect of $5 \mu \mathrm{M} 5$-HT on the NMDA and the AMPA components of the TC EPSC. The NMDA (1) and the AMPA (2) components of the TC responses were recorded in the same neuron at +30 and at $-80 \mathrm{mV}$, respectively. At each potential, the TC EPSCs were recorded in control, in $5 \mu \mathrm{M}$ 5-HT applied for $5 \mathrm{~min}$, and during recovery. Sequential individual TC EPSCs $(n=$ 5) at $+30 \mathrm{mV}(1)$ and at $-80 \mathrm{mV}$ (2). 3, The amplitude of the NMDA and AMPA components were normalized to the responses in control $(1.00 \pm 0.15, n=50$; $1.00 \pm 0.17, n=30$; at +30 and $-80 \mathrm{mV}$, respectively), and the relative amplitude of the EPSC was plotted against time as individual values (circles) and running average $(n=9 ;$ continuous line $)$ at +30 and -80 $\mathrm{mV}$. 5-HT induced a significant reduction $(p<0.0001)$ of the TC EPSC at +30 and $-80 \mathrm{mV}$. The minimal relative amplitude of the TC EPSC reached in 5-HT was similar at +30 and $-80 \mathrm{mV}(0.16 \pm 0.28$ and $0.28 \pm 0.19 ; n=10$, respectively).
$5-\mathrm{HT} 5 \mu \mathrm{M}$

Recovery
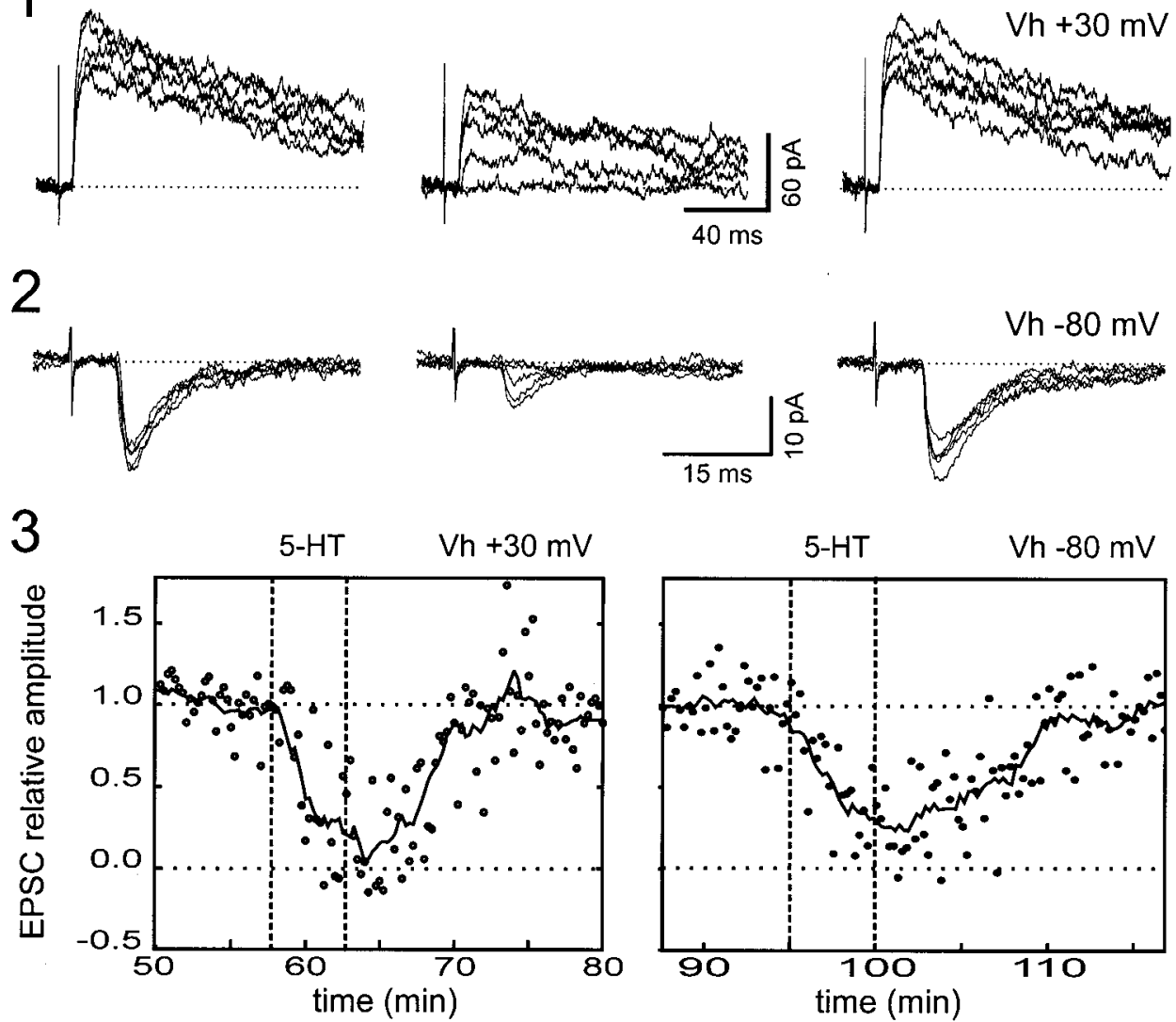

normalization and superimposition of averaged traces in control and in 5-HT (Fig. 3B2; see Fig. 5A2,B2); we found a complete overlap of the traces in control and in 5-HT in 10 cells recorded at $-80 \mathrm{mV}$ and in 10 different cells recorded at $+30 \mathrm{mV}$. The kinetics of the TC EPSC was also quantified by the measurement in 10 cells of the time constant of decay of the TC EPSC recorded at $-80 \mathrm{mV}$ in control and in 5-HT. At $-80 \mathrm{mV}$ the AMPA-KA and the NMDA receptors contribute to the decay of the EPSC. When the relative amplitude of the EPSC was reduced by 5-HT to a minimum $(0.25 \pm 0.17 ; n=10)$, the weighted time constant of decay of the EPSC was not significantly different (4.96 \pm 0.77 and $5.02 \pm 0.82 \mathrm{msec} ; n=10$, in control and in 5-HT, respectively).

To compare the effect of 5-HT on the NMDA and AMPA-KA components of the TC EPSC, we also quantified the relative inhibitory effect of 5-HT on the TC EPSC recorded at +30 and at $-80 \mathrm{mV}$. As discussed earlier (Fig. 2), the NMDA receptors and the AMPA-KA receptors contribute exclusively to the peak of the EPSC recorded at +30 and at $-80 \mathrm{mV}$, respectively. In one single neuron, the effect of $5 \mu \mathrm{M} 5$-HT was tested at both potentials (Fig. 4). We found that the minimal relative amplitude of the TC EPSC reached at the end of the 5-HT application was similar at $+30 \mathrm{mV}(0.16 \pm 0.28)$ and at $-80 \mathrm{mV}(0.28 \pm 0.19)$, indicating that the NMDA and the AMPA-KA components of the TC EPSCs were similarly reduced by 5-HT. However comparing the effect of 5-HT at +30 and $-80 \mathrm{mV}$ in the same neuron requires excellent recording conditions for at least $90 \mathrm{~min}$ that are very difficult to obtain in the neonate. Therefore, we compared the effect of $10 \mu \mathrm{M} 5$-HT in two separate samples of layer IV neurons: six cells were recorded at $-80 \mathrm{mV}$, and four cells at were re- corded at $+30 \mathrm{mV}$ (Fig. 5). We found that the minimal relative amplitude of the EPSC obtained in $10 \mu \mathrm{M} 5$-HT was similar at -80 and at $+30 \mathrm{mV}(0.25 \pm 0.30, n=6 ; 0.22 \pm 0.15, n=4$, respectively) confirming that 5 -HT reduces similarly the AMPA-KA and the NMDA components of the TC EPSC. These results support the idea that the inhibitory effect of 5-HT on the TC EPSC is attributable to a presynaptic reduction of the release of glutamate by the TC axons.

When a synapse is activated twice at short intervals, a reduction [paired pulse depression (PPD)] or a facilitation [paired pulse facilitation (PPF)] of the second EPSC is often seen. PPD and PPF are sensitive to presynaptic changes of transmitter release and insensitive to changes of the postsynaptic receptor sensitivity (Manabe et al., 1993) when AMPA receptors do not express polyamine block (Rozov and Burnashev, 1999). We have seen before that the early component of the TC EPSC displays a linear $I-V$ curve typical of AMPA receptors insensitive to polyamines (Fig. 2). The absence of inward rectification is probably not attributable to the absence of spermine in the pipette solution because the dissipation of the polyamine is slow in the whole-cell configuration, and inward rectification is recorded in such condition (Kidd and Isaac, 1999; Métin et al., 2000). Therefore, the short-term changes of the EPSC depend mainly on a presynaptic modification of the amount of glutamate release. PPD and PPF can be quantified by the paired pulse ratio (PPR) that is the amplitude ratio of the second response to the first response $\left(a_{2} / a_{1}\right)$. To estimate the PPR in control and in $10 \mu \mathrm{M} 5$-HT, two IC stimuli were applied at $20 \mathrm{msec}$ intervals in six cells (Fig. 6). We confirmed that in the neonate TC slice preparation, it was 


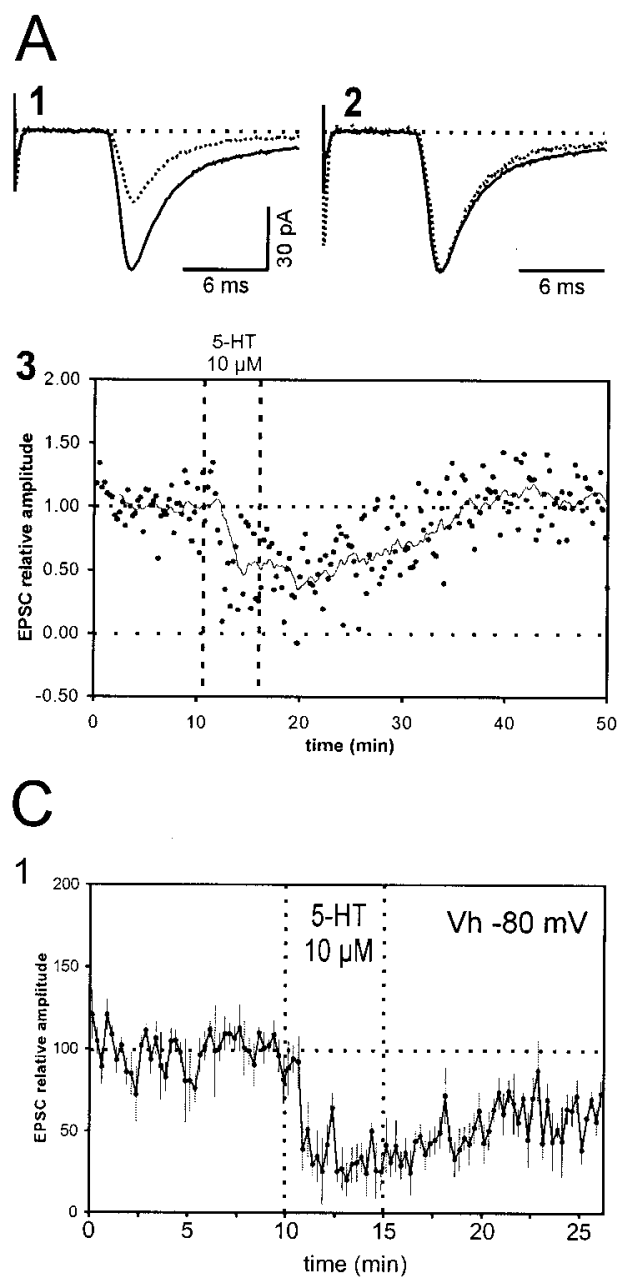

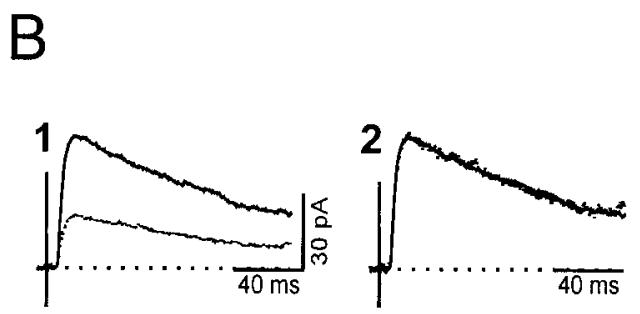
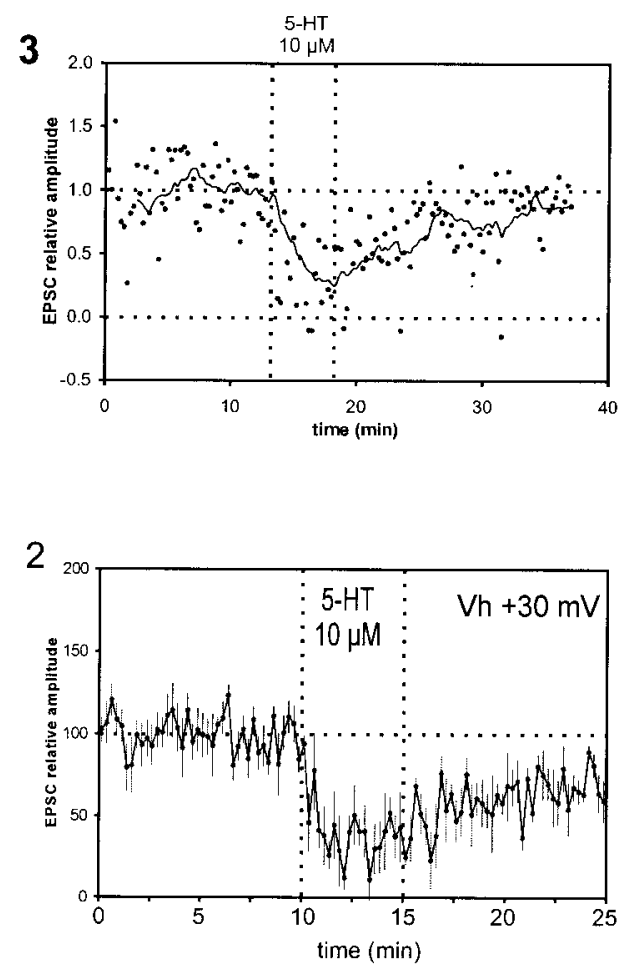

Figure 5. Inhibitory effect of $10 \mu \mathrm{M}$ 5-HT on the AMPA and NMDA components of the TC EPSC. The effect of 10 $\mu \mathrm{M}$ 5-HT applied for $5 \mathrm{~min}$ was compared in different layer IV neurons recorded at -80 or at $+30 \mathrm{mV}$. $A$, In one neuron, the effect of $10 \mu \mathrm{M} 5-\mathrm{HT}$ was tested on the AMPA component of TC EPSC recorded at $-80 \mathrm{mV}$. $B$, In another neuron, the effect of $10 \mu \mathrm{M}$ 5-HT was tested on the NMDA component of the TC EPSC recorded at $+30 \mathrm{mV}$. $A, B$, Traces in control (thick line) and during the responses to 5-HT (dotted line) were averaged $(n=20)$ superimposed (1), and normalized (2). The inhibitory effect of 5-HT (1) did not change the kinetics of the TC EPSC at -80 or at +30 $\mathrm{mV}$ (2). 3, The amplitude of the EPSC was normalized to the response in control, and the relative amplitude was plotted against time as individual values (dots) and running average $(n=10$; continuous line). In each neuron, the relative amplitude of the TC EPSC was significantly $(p<0.0001)$ reduced at both potentials at the end of the 5-HT application (from $1.00 \pm 0.21, n=50$ to $0.52 \pm$ $0.25, n=10$ at $-80 \mathrm{mV}$; and from $1.00 \pm$ $0.25, n=50$ to $0.28 \pm 0.30, n=10$ at + $30 \mathrm{mV}$ ). $C$, Summary data (mean \pm SEM) of the inhibitory effect of $10 \mu \mathrm{M}$ 5-HT on the AMPA ( $1 ; n=6$ cells) and NMDA $(2 ; n=4$ cells) components of the TC EPSC. The minimal relative amplitude of the TC EPSC at the end of the 5-HT application was not significantly different at $-80 \mathrm{mV}(0.25 \pm 0.30 ; n=6)$ and at $+30 \mathrm{mV}(0.22 \pm 0.15 ; n=4)$. possible to record paired pulse monosynaptic TC EPSCs in isolation without disynaptic IPSCs by examining the responses at 0 $\mathrm{mV}$. The AMPA component of the TC EPSC was recorded at $-80 \mathrm{mV}$. In control, we saw a PPD of the TC EPSC $(\mathrm{PPR}=$ $0.75 \pm 0.04 ; n=6$ ) similar to that reported in mature animals (Gil et al., 1997, 1999). The inhibitory effect of $10 \mu \mathrm{M} 5$-HT on the first TC EPSC (39 $\pm 18 \mathrm{pA}$ in control and $12 \pm 10 \mathrm{pA}$ in 5-HT; $n=$ $6)$ was associated with a PPF of the TC EPSC (PPR $=2.23 \pm$ $1.05 ; n=6)$. After removal of 5-HT, full recovery of the first EPSC amplitude and of the PPD were obtained $(\mathrm{PPR}=0.88 \pm$ $0.15 ; n=6)$. These results are consistent with a presynaptic inhibitory action of 5-HT on the release of glutamate by the TC relay neurons.

Spontaneous bursts of activity have been recorded in the TC pathways during development, and it has been proposed that they play an important role in the activity-dependent refinement of the axonal projections in sensory systems (Weliky and Katz, 1999). To investigate the possibility that 5 -HT regulates the propagation of the spontaneous burst of activity in the TC pathways of the neonate mice, we decided to test the effect of 5-HT on the responses to high-frequency $(50 \mathrm{~Hz})$ trains of five IC stimuli (Fig. $6 B$ ) reminiscent of the bursts seen in vivo (Weliky and Katz, 1999). The experiments $(n=4)$ were done in the presence of $\mathrm{GABA}_{\mathrm{A}}$ and NMDA receptor antagonists to isolate the AMPA-KA component of the TC EPSC. We compared the effect of $50 \mathrm{~Hz}$ trains of IC stimulation in control and in $10 \mu \mathrm{M}$ 5-HT. In control the IC trains induced a progressive decline of the TC
EPSC amplitude or short-term depression similar to that seen in older rodents (Gil et al., 1997, 1999). In $10 \mu \mathrm{M}$ 5-HT, we found a reduction of the first TC EPSC amplitude ( $39 \pm 16$ and $7 \pm 5 \mathrm{pA}$; $n=4$; in control and in 5-HT, respectively; $p<0.01)$. At the same time, the short-term depression seen in control $\left(R_{2}=0.79 \pm 0.19\right.$; $\left.R_{3}=0.58 \pm 0.29 ; R_{4}=0.27 \pm 0.09 ; R_{5}=0.17 \pm 0.10 ; n=4\right)$ was changed into a short-term facilitation in $10 \mu \mathrm{M} 5$-HT $\left(R_{2}=1.83 \pm\right.$ $1.02 ; R_{3}=2.03 \pm 0.30 ; R_{4}=1.48 \pm 0.71 ; R_{5}=1.28 \pm 0.59 ; n=$ 4); $R_{4}$ and $R_{5}$ were significantly different in control and in 5-HT $(p<0.01)$. These results show that the effect of 5 -HT on the TC EPSC depends on the recent history of the TC synapse and that 5-HT may change the propagation of high-frequency bursts of TC activity in the primary somatosensory TC pathways of the neonatal mice.

\section{5-HT1B receptors mediated the presynaptic inhibitory action of 5-HT}

Previous studies using a genetic approach have shown that the excessive activation of the 5-HT1B receptors plays a critical role in the appearance of the barrelless phenotype in the MAOA knock-out mice (Salichon et al., 2001). It has also been shown that 5-HT1B receptor binding sites disappear after thalamic lesion and are present in the layer IV of S1 cortex in P8 rats and mice (Leslie et al., 1992; Cases et al., 1996), suggesting that 5-HT1B receptors are expressed by the axon terminals of the VB relay neurons (Bennett-Clarke et al., 1993). Substantial coexpression of the 5-HT1B and 5-HT1D receptors has also been reported in the 
Figure 6. Activity-dependent effect of 5-HT on the TC EPSC. $A$, A $10 \mu \mathrm{M}$ concentration of 5-HT converts the paired pulse depression of the control into a paired pulse facilitation. 1, TC EPSCs evoked by two IC stimuli applied at $20 \mathrm{msec}$ interval every $15 \mathrm{sec}$ and recorded at $-80 \mathrm{mV}$. The averaged $(n=$ 20) TC EPSCs are shown in control (thick trace), during the response to 10 $\mu \mathrm{M}$ 5-HT (dotted trace), and after recovery (thin trace). 2, 3, In the same neuron, the amplitude of the first $\left(a_{1}\right)$ and the second $\left(a_{2}\right)$ TC EPSCs are plotted against time; individual (dots) and running average ( $n=10$; continuous line) are shown. The application of $10 \mu \mathrm{M} 5-\mathrm{HT}$ for 5 min induced a significant $(p<$ $0.0001)$ reduction of the first EPSC without changing the second EPSC $\left(a_{2}\right)$, and the PPD of the control was converted into a PPF in 5-HT. 4, The PPR calculated from the running average $(n=10)$ is plotted against time. The maximal PPR in 5 -HT $(2.33 \pm 0.34 ; n=10)$ was significantly $(p<0.0001)$ different from the PPR in control $(0.82 \pm 0.11 ; n=45)$. 5 , Summary data of the effect of $10 \mu \mathrm{M}$ 5-HT applied for $5 \mathrm{~min}$ on the PPR in six cells. Individual (continuous lines) and mean (discontinuous line) PPRs are plotted in control during the inhibitory effect of 5-HT and after recovery. The inhibitory effect of 5-HT reduced the EPSC to a minimal normalized value of $0.28 \pm$ $0.12(n=6)$ and changed the PPD of the control into a PPF in 5-HT. The PPR of the control $(0.75 \pm 0.04 ; n=6)$ was significantly $(p<0.01)$ different from the PPR in $5-\mathrm{HT}(2.23 \pm 1.05 ; n=6)$. After recovery the PPR $(0.82 \pm 0.15 ; n=6)$ was not different from the control. $B$, 5-HT changes the short-term depression of the control into a short-term facilitation. 1, Averaged $(n=40)$ TC EPSC in response to a train of five high-frequency $(50 \mathrm{~Hz})$ IC stimuli applied every $15 \mathrm{sec}$ in control (thick line) and during the inhibitory effect of $10 \mu \mathrm{M}$ 5-HT (thin line). We applied $10 \mu \mathrm{M}$ BIC and $50 \mu \mathrm{M}$ D-AP-5 during the whole session. The successive TC EPSCs of the train were normalized to the first response $\left(R_{2-5}=a_{2-}{ }_{5} / a_{1}\right)$. In 5-HT, the amplitude of the first EPSC was reduced to $13 \%$ of its control value. In control, the repetitive stimulation induced a short-term depression of the TC EPSCs $\left(R_{2}=0.74 ; \mathrm{R}_{3}=0.44 ; \mathrm{R}_{4}=0.23 ; \mathrm{R}_{5}=0.15\right)$ that was changed into a short-term facilitation in 5-HT $\left(R_{2}=1.20 ; \mathrm{R}_{3}=2.00 ; \mathrm{R}_{4}=2.00 ; \mathrm{R}_{5}=1.40\right) .2$, Summary data (mean $\left.\pm \mathrm{SEM}\right)$ of the effect of 5-HT on the short-term changes of the TC EPSC in four layer IV cells. In abscissa is shown the stimulus number in the train, in the ordinate the EPSC amplitude normalized to the first response $\left(R_{\mathrm{n}}\right)$. 5-HT induced a significant $(p<0.01)$ inhibition of the first TC EPSC $(39 \pm 16 \mathrm{pA}$ in control; $7 \pm 5 \mathrm{pA} ; n=4$ in 5 -HT $)$, associated with a change of the short-term depression seen in control (continuous line) into a short-term facilitation in 5-HT (dashed line).

adult rat brain (Bruinvels et al., 1993). Both receptor types are addressed to axon terminals and are negatively coupled to adenylyl cyclase (Maroteaux et al., 1992). In embryos, the expression of the 5-HT1D receptors appears to precede the expression of the 5-HT1B receptors (Bolanos-Jimenez et al., 1997), raising the possibility that both the 5-HT1B and the 5-HT1D receptors may contribute to the effect of 5-HT on the TC EPSC of the neonatal mice.

To investigate this possibility we studied the distribution of the 5-HT1B and 5-HT1D receptors in the somatosensory TC pathways during development by in situ hybridization (Fig. 7). Fulllength mRNA probes were used to compare the distribution of the 5-HT1B and 5-HT1D receptor mRNAs in neonate and adult mice. We observed 5-HT1B receptor gene expression in the dorsal lateral geniculate nucleus (dLGN) and in the VB thalamic nucleus from P0 to P7. This expression decreased by P10 and had completely disappeared by P14 (Fig. $7 F$ ). In S1 cortex, 5-HT1B receptor mRNAs were detected only in the infragranular cortical layers, essentially in layer V. The expression of the 5-HT1D receptor mRNAs was very low at $\mathrm{P} 4, \mathrm{P} 7$, and in adults: a weak signal was detected in the striatum, and no signal was found in the somatosensory thalamic and cortical structures (data not shown).

According to our in situ hybridization studies (Fig. 7), the expression of 5-HT1B receptor mRNA by the TC relay neurons is transient and disappears after the second week of life. To further investigate the possible implication of the 5-HT1B receptor in the regulation of the TC activity in the neonate and to test whether the effect of 5-HT is developmentally regulated, we studied the effect of 5-HT on the TC EPSC in older mice (23 $\pm 4 \mathrm{~d} ; n=22)$. The AMPA component of the monosynaptic TC EPSC was recorded at $-80 \mathrm{mV}$ in the presence $\mathrm{GABA}_{\mathrm{A}}$ antagonists to block the disynaptic TC IPSC evoked by the minimal IC stimulation in the older mice and in the presence of AP-5 to prevent seizure activity (see Materials and Methods). We found that in mice 

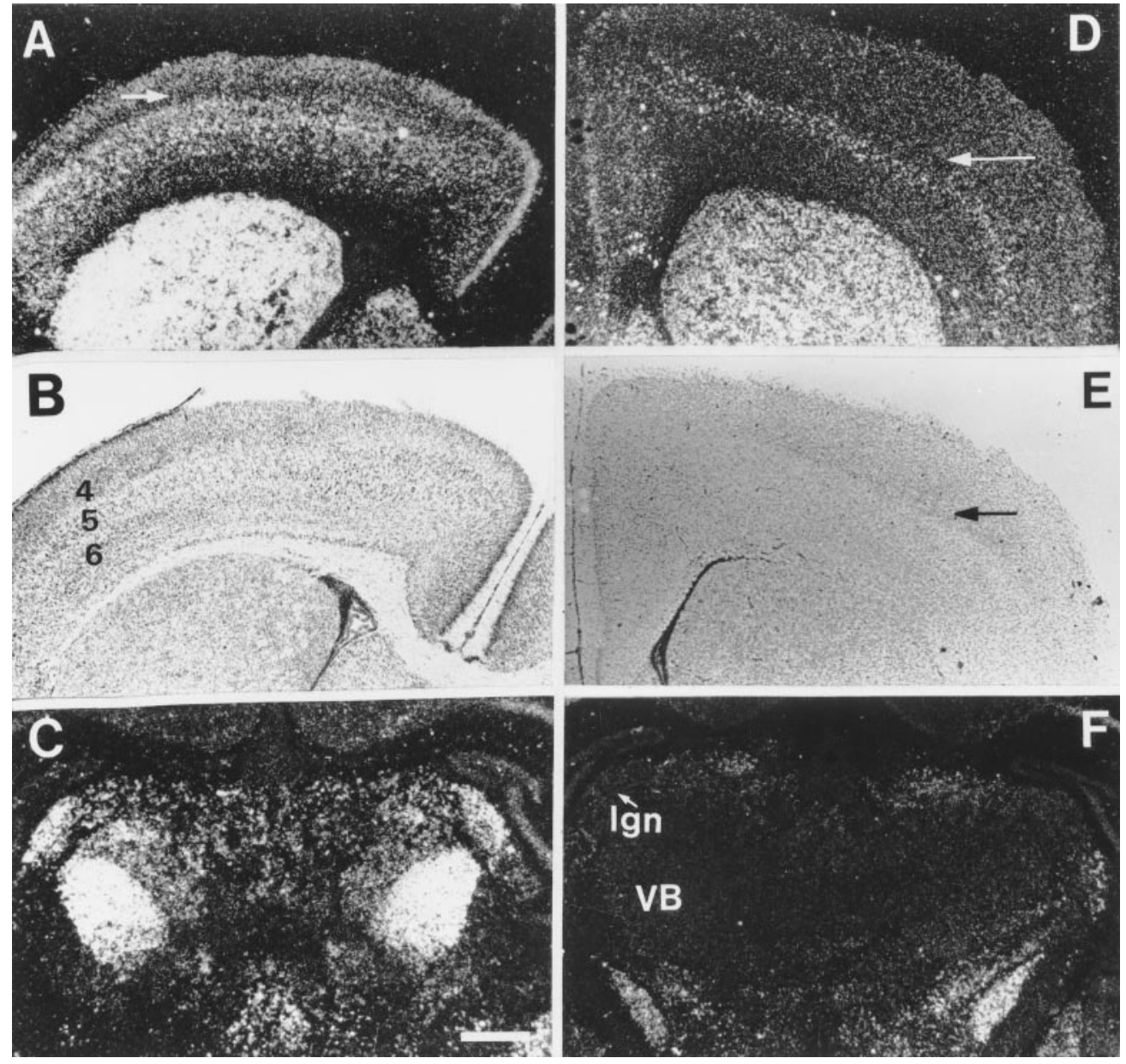

Figure 7. Transient expression of 5-HT1B receptor mRNAs in the mouse somatosensory system. Expression pattern is illustrated at $\mathrm{P} 7(A, C)$ and $\mathrm{P} 15(D, F)$ in the cerebral cortex $(A, D)$ and the thalamus $(C, F)$. Nissl-counterstained sections are shown for the cortex to illustrate the layer IV in S1 cortex where the recordings were done $(B, E)$. In $\mathrm{S} 1$ cortex, the specific hybridization signal is limited to layer V at P7 and P15, although the relative extent of the expression appears to be broader at $\mathrm{P} 7$ than at $\mathrm{P} 15$ (the position of the cortical layers is indicated by roman numbers). In the thalamus, a strong hybridization signal is visible in the dLGN and the VB at P7 but is absent at P15. Scale bar, $450 \mu \mathrm{m}$. older than $21 \mathrm{~d}$, the latency of the TC EPSC and the variability of the latency were smaller than in the neonate, as expected from the axonal myelin formation (Table 1). The effect of $10 \mu \mathrm{M} \mathrm{5-HT}$ applied for 5 min was tested in six cells (Fig. 8). We found that the amplitude of the AMPA component of the TC EPSC was very slightly reduced by 5-HT. Within individual neurons, the effect of 5-HT was weak and not consistent. When the cells were averaged, we found a small reduction the EPSC amplitude with a minimal relative value $(0.89 \pm 0.06 ; n=6)$; significantly smaller than the control $(p<0.0001)$, but the inhibitory effect of 5-HT was significantly smaller $(p<0.001)$ in older mice than in the neonate (compare Figs. 5C1 and $8 B$ ). These results show that during barrel development the downregulation of the 5-HT1B receptor mRNA expression in the VB relay neurons is correlated with a significant reduction of the effect of 5-HT on the TC EPSC. They also indicate that in older mice 5-HT receptors other than 5-HT1B receptors are probably not involved in the control of the TC EPSC.

To further investigate the possible implication of the 5-HT1B receptors in the effect of 5-HT on the TC EPSC, we studied the effect of CP93129 (100 nM), a specific 5-HT1B agonist, on the TC EPSC evoked by a single IC stimulus and recorded at $+30 \mathrm{mV}$ (Fig. 9). In all tested cells $(n=4)$, we found that CP93129 induced a significant $(p<0.0001)$ and reversible reduction of the TC EPSC. These results indicate that the activation of the 5-HT1B receptors mimics the effect of 5-HT on the TC EPSC in the somatosensory system of the neonatal mice.

Finally, to examine the specificity of the effect of 5-HT1B receptors on the TC EPSC of the neonate, we tested the effect of
5-HT on the TC EPSC in the layer IV barrels of the neonatal 5-HT1B receptor knock-out mice (Fig. 10). In these mice, we found that the minimal stimulation of the IC evoked monosynaptic unitary EPSCs with the same characteristics as in the wild-type mice (Table 1), indicating that 5-HT1B receptors are not critically involved in the development of the TC synapses. Both the NMDA and the AMPA components of the TC EPSC appear normal, and their relative contribution was not significantly different from that observed in the wild-type neonate mice. We also observed a PPD of the TC EPSC with $50 \mathrm{~Hz}$ IC stimulation with a PPR similar to that seen in the neonate wild-type mice (Table 1). We also found that the bath application of $10 \mu \mathrm{M}$ 5-HT in the 5-HT1B receptor knock-out neonate mice could still induce an increase of the frequency of the spontaneous unitary EPSCs similar to that seen in wild-type neonate mice, supporting the idea that this effect of 5-HT on spontaneous EPSC is not attributable to 5-HT1B receptors. In contrast, $10 \mu \mathrm{M}$ 5-HT applied for $5 \mathrm{~min}$ on five neurons had no effect on the amplitude of TC EPSC recorded at $-80 \mathrm{mV}$ in the 5-HT1B receptor knock-out mice (Fig. 10). These results support our pharmacological and in situ hybridization data showing that 5-HT1B receptors mediate the regulation of the TC EPSC in the neonate wild-type mice. They also indicate that the 5-HT1D receptors do not compensate for the absence of 5-HT1B receptors in the knock-out neonate mice.

\section{DISCUSSION}

In the barrel field of the neonate mice, we demonstrate that 5-HT reduces the monosynaptic TC EPSC evoked by a low-frequency 

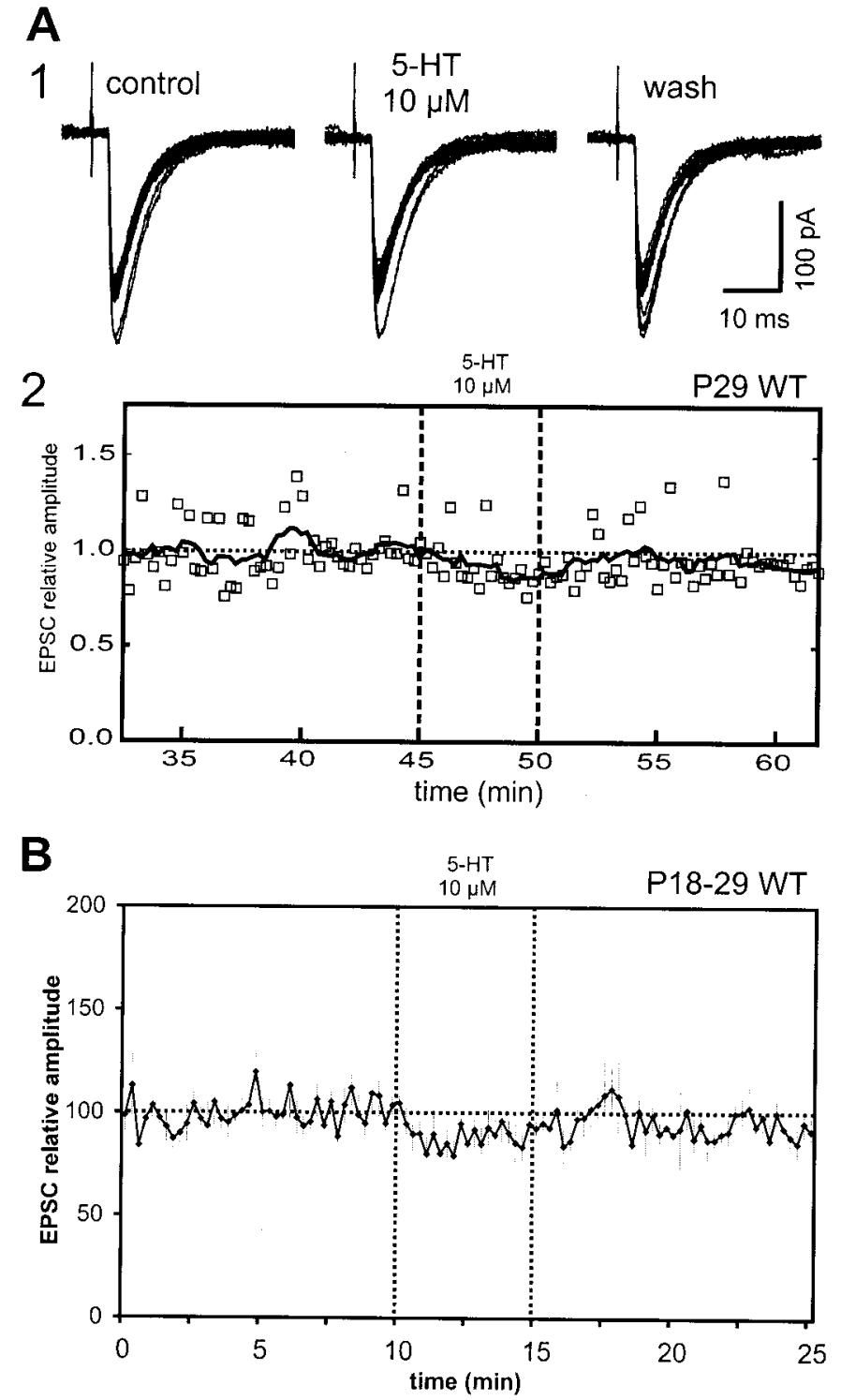

Figure 8. Effect of 5-HT on the TC EPSC in the older wild-type mice. A, The AMPA component of the TC EPSC evoked by the IC stimulation at $0.07 \mathrm{~Hz}$ was recorded at $-80 \mathrm{mV}$ in presence of $100 \mu \mathrm{M} \mathrm{PTX}$ and $100 \mu \mathrm{M}$ D,L-AP-5. 1, Superimposition of sequential individual TC EPSCs $(n=20)$ in control, during the application of $10 \mu \mathrm{M} \mathrm{5-HT}$, and at the end of the recording session. 2, In the same neuron, the TC EPSC amplitudes were normalized to the mean value in control $(176 \pm 25 \mathrm{pA} ; n=50)$. The individual values (squares) and the running average (continuous line) of the relative amplitude of TC EPSC are plotted against time. The application of $10 \mu \mathrm{M} 5$-HT for 5 min induced a very small reduction of the TC EPSC amplitude with a minimal value $(0.87 \pm 0.06 ; n=10)$ significantly $(p<0.01)$ different from the control $(1.00 \pm 0.14 ; n=40)$. $B$, Summary data of the effect of $10 \mu \mathrm{M} 5-\mathrm{HT}$ on the AMPA component of TC EPSC recorded in six cells from wild-type mice between P18 and P29. The mean (continuous line) and the SEM (vertical lines) are plotted against time. At the end of the application of $10 \mu \mathrm{M} 5$-HT, the amplitude of the TC EPSC reached a minimal value $(0.89 \pm 0.06 ; n=10)$ significantly $(p<0.01)$ different from the control $(1.00 \pm 0.08 ; n=40)$.

IC stimulation. We also provide the first evidence that the effect of 5-HT depends on TC activity because 5-HT relieves the short-term depression induced by high-frequency IC stimulation. As first suggested by Rhoades et al. (1994), we show that the effect of 5-HT is caused by a presynaptic action on the release of glutamate by the TC fibers, and we demonstrate that
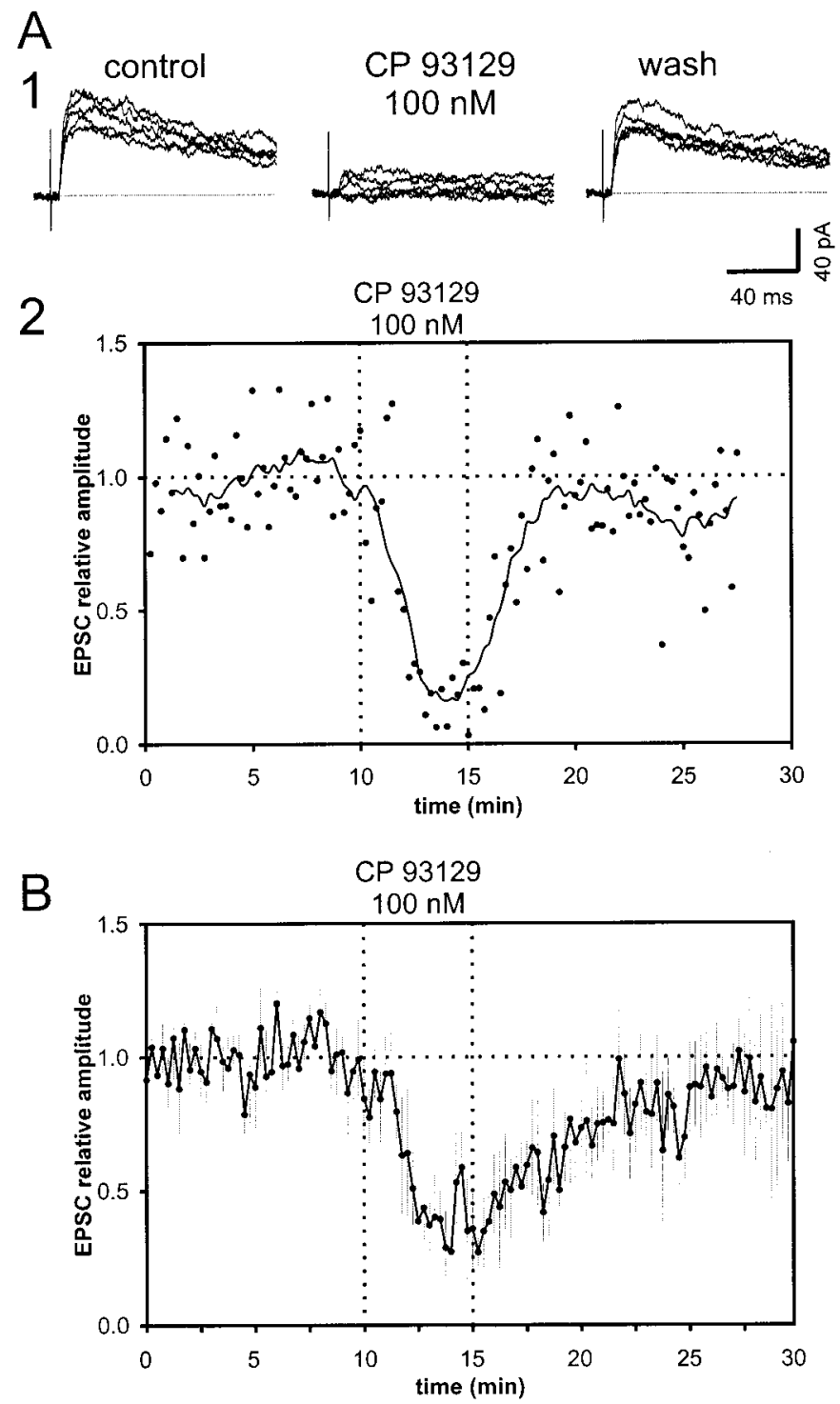

Figure 9. CP93129, a 5-HT1B receptor agonist, mimics the inhibitory effect of 5-HT on the TC EPSC in the neonate wild-type mice. $A$, In a neuron maintained at $+30 \mathrm{mV}$, the NMDA component of the TC EPSC was evoked by IC stimulation at $0.07 \mathrm{~Hz}$ in control and during the application of $100 \mathrm{~nm} \mathrm{CP93129} \mathrm{for} 5 \mathrm{~min}$. 1, Superimposition of sequential individual TC EPSCs $(n=5)$ in control, during the response to $100 \mathrm{nM}$ CP93129, and after recovery. CP93129 induced a reversible reduction of the TC EPSC amplitude, and failures occurred. 2, The amplitude of the TC EPSC was normalized to the mean amplitude in control $(84 \pm 14 \mathrm{pA}$; $n=40$ ). The individual (dots) and running average (continuous line) of the relative amplitude of TC EPSCs are plotted against time. The relative amplitude of the TC EPSC reached minimal value $(0.16 \pm 0.09 ; n=10)$ in $100 \mathrm{~nm} \mathrm{CP93129} \mathrm{that} \mathrm{was} \mathrm{significantly}(p<0.0001)$ different from the control $(1.00 \pm 0.17 ; n=40)$. $B$, Summary data (mean \pm SEM) of the effect of $100 \mathrm{~nm}$ CP93129 applied for $5 \mathrm{~min}$ in four cells. The recording conditions are identical to those described in $A$. The minimal relative amplitude of the TC EPSC reached in $100 \mathrm{nM} \mathrm{CP93129}(0.35 \pm 0.33 ; n=$ 4) was significantly different from the control.

the effect of 5-HT appears to rely exclusively on 5-HT1B receptors. Our results support the hypothesis that the excessive activation of 5-HT1B receptors that takes place in MAOA knock-out mice during the critical period (Cases et al., 1996; Salichon et al., 2001) may prevent the barrel formation by changing TC activity. 
A

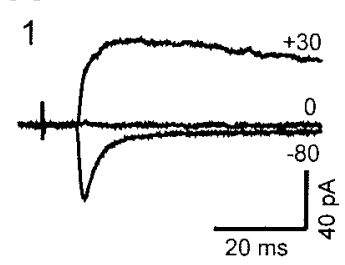

B

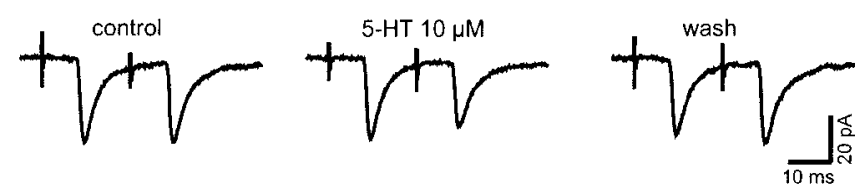

C

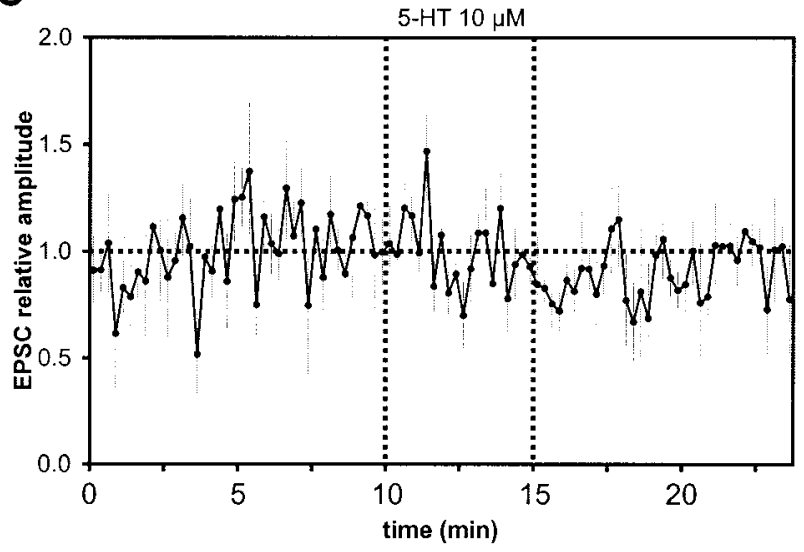

Figure 10. The TC EPSC of the 5-HT1B receptor knock-out neonatal mice is insensitive to 5-HT. $A$, Physiological characterization of the TC EPSC in a neonatal 5-HT1B knock-out mouse evoked by IC stimulation. 1 , The responses displayed a faster kinetics at $-80 \mathrm{mV}$ than at $+30 \mathrm{mV}$ and reversed near $0 \mathrm{mV}$. 2, The latency distribution of the response at $-80 \mathrm{mV}$ was stable $(7.48 \pm 0.14 \mathrm{msec} ; n=80) .3$, The $50 \mathrm{~Hz}$ paired pulse IC stimulation evoked a depression of the second response $(\mathrm{PPR}=0.91)$. $B, 10 \mu \mathrm{M} 5$-HT applied for $5 \mathrm{~min}$ had no inhibitory effect on the TC EPSC in a 5-HT1B knock-out mouse at P5. The averaged $(n=10)$ TC EPSC recorded at $-80 \mathrm{mV}$ was evoked by a paired pulse IC stimulation in control, during the application of 5-HT and after washing 5-HT. The application of 5-HT had no significant effect on the amplitude of the first TC EPSC ( $37.73 \pm 18.51 \mathrm{pA}, n=39$ in control; $37.87 \pm 17.27 \mathrm{pA}, n=20$ in 5-HT) and on the PPR (0.95 and 1.03 in control and in 5-HT, respectively). $C$, Summary data of the results (mean \pm SEM) obtained in five cells from 5-HT1B receptor knock-out mice. $10 \mu \mathrm{M}$ 5-HT applied for $5 \mathrm{~min}$ had no effect on the amplitude of the first TC EPSC recorded at $-80 \mathrm{mV}$.

\section{Presynaptic effect of the 5-HT1B receptor activation on TC excitatory transmission}

The stimulation of the VB thalamic nucleus evokes a monosynaptic EPSC in layer IV neurons that results probably from the release of glutamate by ascending TC axons. As shown before in older mice (Agmon and Connors, 1991), IC stimulation that could activate neurons in layers V/VI and cause the release of glutamate by corticocortical collaterals of layer VI pyramidal neurons to layer IV (Zhang and Deschenes, 1997). To investigate this possibility we used whole-cell and extracellular field recordings in the layers V/VI of TC slices with a functional monosynaptic connection between the IC and the layer IV S1 cortex. We recorded no antidromic responses in the infragranular layers of S1 cortex. Therefore, although we cannot completely exclude a minor contribution of descending $\mathrm{CT}$ axons, the monosynaptic
EPSCs evoked in layer IV S1 cortex by IC stimulation result probably mainly from the release of glutamate by ascending TC axons. This advantageous feature of the TC slice preparation may be attributable to the slightly different trajectories of ascending and descending fibers (Bicknese et al., 1994).

It has been shown previously that 5-HT reduces the EPSPs evoked by VB stimulation in S1 cortex (Rhoades et al., 1994), but most neurons were recorded in layer $\mathrm{V}$ and the EPSPs were polysynaptic, raising the question of the site of action of 5-HT. Our recordings were obtained from neurons in layer IV, as demonstrated by the localization of their soma in the barrels; they receive a direct input from the $\mathrm{VB}$ thalamic nucleus (White, 1978). We showed that the latency of the TC EPSC exhibits little variability and follows a Gaussian distribution, as expected for a monosynaptic response. Therefore the effect of 5-HT that we analyzed in layer IV neurons was probably restricted to TC synapses.

Our in situ hybridization and physiological data show that 5-HT acts presynaptically on the glutamate release by TC terminals via the activation of 5-HT1B receptors. The possible transient expression of the 5-HT1B receptor by the TC terminals has been previously assessed by combining lesions and binding of a 5-HT1B agonist cyanopindolol (Bennett-Clarke et al., 1993). We used full-length mRNA riboprobes to provide direct evidence for a transient expression of the 5-HT1B receptor gene in the VB thalamic neurons during postnatal development. We also showed that within S1 cortex, the expression of the 5-HT1B receptor gene remains confined to neurons in layer $\mathrm{V}$ in the neonatal and adult mice. This is in contrast to previous descriptions of a 5-HT1B receptor mRNA expression in layer IV S1 cortex of the adult rodents (Voigt et al., 1991; Boschert et al., 1994). Our physiological results using CP93129, a specific 5-HT1B agonist, show also that the activation of 5-HT1B receptors reduces the monosynaptic TC EPSC. Finally we show that 5-HT1B receptors appear to contribute exclusively to the inhibition of the TC EPSC: first, we were unable to detect 5-HT1D receptor gene expression in the thalamus and cerebral cortex; second, the downregulation of the expression of the 5-HT1B receptor gene in the VB thalamic nucleus was correlated to a decrease of the sensitivity of the TC EPSC to 5-HT in mice older than 3 weeks; third, we showed that in the neonate $5-\mathrm{HT} 1 \mathrm{~B}$ receptor knock-out mice, the TC synaptic contacts were functional, but the TC EPSCs were insensitive to 5-HT. Our results demonstrate also that the inhibitory effect of 5-HT on the TC EPSC is caused by a presynaptic reduction of the release of glutamate by the VB relay neurons: first, we found a similar inhibitory effect of 5-HT on the AMPA and the NMDA components of the TC EPSC; second, the effect of 5-HT is associated with a change of the paired pulse ratio and a relief of the short-term depression of the TC EPSC. A presynaptic effect of 5-HT through 5-HT1B heteroreceptors has also been reported on retinal inputs to the superior colliculus (Mooney et al., 1994) and to the suprachiasmatic nucleus (Pickard et al., 1999), where the effect was maintained in adults.

Postsynaptic 5-HT1A and 5-HT2 receptors are expressed by cortical neurons (Hoyer et al., 1994) and control potassium channel activity (Andrade and Nicoll, 1987; McCormick, 1992). Their contribution to the inhibition of the TC EPSC by 5-HT is unlikely because the recording pipettes contained cesium, a potassium channel blocker. A possible contribution of 5-HT3 receptors found in developing sensory cortex (Roerig and Katz, 1997; Roerig et al., 1997), is also unlikely because 5-HT did not induce a postsynaptic current. The possibility that 5-HT1A, 5-HT2, and 
5-HT3 receptors contribute to the increase of spontaneous unitary IPSCs and EPSCs in the neonate S1 cortex remains to be studied.

\section{Possible effects of the 5-HT1B receptor activation on the barrel formation}

Experimental evidence indicate that both neuronal activity (Schlaggar et al., 1993; Fox et al., 1996; Iwasato et al., 1997, 2000) and guidance molecules (Prakash et al., 2000) influence the formation of barrels that appears to result from two distinct cellular mechanisms. Presynaptically, the TC axons segregate within specific barrels. Postsynaptically the soma of the layer IV spiny stellate neurons accumulate at the periphery of the barrel and extend dendrites toward the center where synaptic contacts are established with the TC axons (Harris and Woolsey, 1981; Lubke et al., 2000).

Although 5-HT modulates TC neurotransmission, it does not appear to be critically involved in the development of barrels because the layout of the barrel field is normal in 5-HT-deprived mice (Bennett-Clarke et al., 1994). In the 5-HT1B receptor knock-out mice, the effect of 5-HT on the TC transmission is lost during development (Fig. 10), but normal barrels are still formed (Salichon et al., 2001). These results indicate that with normal 5-HT levels, glutamate- and NMDA-dependent mechanisms appear sufficient to instruct barrel formation. However, the importance of 5-HT for barrel formation may be more subtle, as shown by the reduced barrel size (Bennett-Clarke et al., 1994) and by the modification of the critical period (Osterheld-Haas et al., 1994) induced by 5 -HT deprivation. Therefore, a possible involvement of 5-HT1B receptors for the plasticity of the barrels requires further investigation. The situation is different in the MAOA knock-out mice with excessive 5-HT levels (Cases et al., 1996) in which the overactivation of 5-HT1B receptors disrupts the barrel formation. Our results indicate that the 5-HT1B receptors could mediate their effect by an abnormal control of release of glutamate by the TC fibers. Other 5-HT receptors may also mediate postsynaptic abnormalities that are maintained in the MAOA/5HT1B receptor double knock-out mice (Salichon et al., 2001).

Genetic approaches have shown that cortical NMDA receptors and type 5 metabotropic glutamate receptors (mGluR5) are critical for postsynaptic cortical changes (Iwasato et al., 2000; Hannan et al., 2001) and that 5-HT1B receptors are necessary for the segregation of the TC fibers (Salichon et al., 2001). cAMP is another important molecule for the segregation of the TC fibers, because in the barrelless $b r l$ mouse mutant strain that lack the adenylyl cyclase 1 activity (Abdel-Majid et al., 1998), the TC axonal arbors extend to adjacent barrels (Welker et al., 1996). 5-HT1B receptors are negatively coupled to adenylyl cyclase (Bouhelal et al., 1988), and their activation promotes axonal growth (Lieske et al., 1999; Lotto et al., 1999). Therefore the influence of 5-HT1B receptors and adenylyl cyclase 1 on the TC segregation could rely on a trophic action or participate in common activity-dependent mechanisms during the refinement of cortical maps.

The effects of the 5-HT1B receptors cannot be viewed as a simple block of excitatory TC transmission. Indeed, our results showed that the activation of 5-HT1B receptors decreases the TC responses to low-frequency stimulation and relieves the shortterm depression induced by high-frequency TC stimulation. Although we ignore the physiological conditions of 5-HT release, at least two consequences of the 5-HT1B receptor activation can be suggested. First, the activation of the 5-HT1B receptors may inhibit the responses to single TC impulses, favor the transmission of bursts of TC activity (Brenowitz et al., 1998), and recruit preferentially NMDA receptors (Collingridge et al., 1988). Therefore 5-HT may change the NMDA-dependent LTP and LTD of the TC transmission seen in the barrel field during the critical period of development (Crair and Malenka, 1995; Feldman et al., 1998). The activation of 5-HT1B receptors could also promote the propagation of the spontaneous correlated TC activity (Weliky and Katz, 1999) and the activity-dependent refinement of topographic maps (Katz and Shatz, 1996). In conclusion, although we cannot exclude a possible trophic action of 5-HT, our results are compatible with an activity-dependent effect of 5-HT on the barrel formation.

\section{REFERENCES}

Abdel-Majid RM, Leong WL, Schalkwyk LC, Smallman DS, Wong ST, Storm DR, Fine A, Dobson MJ, Guernsey DL, Neumann PE (1998) Loss of adenylyl cyclase I activity disrupts patterning of mouse somatosensory cortex. Nat Genet 19:289-291.

Agmon A, Connors BW (1991) Thalamocortical responses of mouse somatosensory (barrel) cortex in vitro. Neuroscience 41:365-379.

Agmon A, O'Dowd DK (1992) NMDA receptor-mediated currents are prominent in the thalamocortical synaptic response before maturation of inhibition. J Neurophysiol 68:345-349.

Andrade R, Nicoll RA (1987) Pharmacologically distinct actions of serotonin on single pyramidal neurones of the rat hippocampus recorded in vitro. J Physiol (Lond) 394:99-124.

Armstrong-James M, Fox K (1987) Spatiotemporal convergence and divergence in the rat S1 "barrel" cortex. J Comp Neurol 263:265-281.

Barth AL, Malenka RC (2001) NMDAR EPSC kinetics do not regulate the critical period for LTP at thalamocortical synapses. Nat Neurosci 4:235-236.

Bennett-Clarke CA, Leslie MJ, Chiaia NL, Rhoades RW (1993) Serotonin $1 \mathrm{~B}$ receptors in the developing somatosensory and visual cortices are located on thalamocortical axons. Proc Natl Acad Sci USA 90:153-157.

Bennett-Clarke CA, Leslie MJ, Lane RD, Rhoades RW (1994) Effect of serotonin depletion on vibrissa-related patterns of thalamic afferents in the rat's somatosensory cortex. J Neurosci 14:7594-7607.

Bennett-Clarke CA, Chiaia NL, Rhoades RW (1996) Thalamocortical afferents in rat transiently express high-affinity serotonin uptake sites. Brain Res 733:301-306.

Bicknese AR, Sheppard AM, O'Leary DD, Pearlman AL (1994) Thalamocortical axons extend along a chondroitin sulfate proteoglycan-enriched pathway coincident with the neocortical subplate and distinct from the efferent path. J Neurosci 14:3500-3510.

Bolanos-Jimenez F, Choi DS, Maroteaux L (1997) Preferential expression of 5-HT1D over 5-HT1B receptors during early embryogenesis. NeuroReport 8:3655-3660.

Boschert U, Amara DA, Segu L, Hen R (1994) The mouse 5-hydroxytryptamine1B receptor is localized predominantly on axon terminals. Neuroscience 58:167-182.

Bouhelal R, Smounya L, Bockaert J (1988) 5-HT1B receptors are negatively coupled with adenylate cyclase in rat substantia nigra. Eur J Neurosci 151:189-196.

Bourassa J, Pinault D, Deschenes M (1995) Corticothalamic projections from the cortical barrel field to the somatosensory thalamus in rats: a single-fibre study using biocytin as an anterograde tracer. Eur J Neurosci 7:19-30.

Brenowitz S, David J, Trussell L (1998) Enhancement of synaptic efficacy by presynaptic GABAB receptors. Neuron 20:135-141.

Bruinvels AT, Palacios JM, Hoyer D (1993) Autoradiographic characterisation and localisation of 5-HT1D compared to 5-HT1B binding sites in rat brain. Naunyn Schmiedebergs Arch Pharmacol 347:569-582.

Cases O, Vitalis T, Seif I, De Maeyer E, Sotelo C, Gaspar P (1996) Lack of barrels in the somatosensory cortex of monoamine oxidase A-deficient mice: role of a serotonin excess during the critical period. Neuron 16:297-307.

Chagnac-Amitai Y, Connors BW (1989) Synchronized excitation and inhibition driven by intrinsically bursting neurons in neocortex. J Neurophysiol 62:1149-1162.

Chiaia NL, Fish SE, Bauer WR, Bennett-Clarke CA, Rhoades RW (1992) Postnatal blockade of cortical activity by tetrodotoxin does not disrupt the formation of vibrissa-related patterns in the rat's somatosensory cortex. Brain Res Dev Brain Res 66:244-250.

Chiaia NL, Fish SE, Bauer WR, Figley BA, Eck M, Bennett-Clarke CA, Rhoades RW (1994) Effects of postnatal blockade of cortical activity with tetrodotoxin upon lesion-induced reorganization of vibrissae- 
related patterns in the somatosensory cortex of rat. Brain Res Dev Brain Res 79:301-306.

Collingridge GL, Herron CE, Lester RA (1988) Frequency-dependent $N$-methyl-D-aspartate receptor-mediated synaptic transmission in rat hippocampus. J Physiol (Lond) 399:301-312.

Crair MC, Malenka RC (1995) A critical period for long-term potentiation at thalamocortical synapses. Nature $375: 325-328$

D'Amato RJ, Blue ME, Largent BL, Lynch DR, Ledbetter DJ, Molliver ME, Snyder SH (1987) Ontogeny of the serotonergic projection to rat neocortex: transient expression of a dense innervation to primary sensory areas. Proc Natl Acad Sci USA 84:4322-4326.

Feldman DE, Nicoll RA, Malenka RC, Isaac JT (1998) Long-term depression at thalamocortical synapses in developing rat somatosensory cortex. Neuron 21:347-357.

Feldmeyer D, Egger V, Lubke J, Sakmann B (1999) Reliable synaptic connections between pairs of excitatory layer 4 neurones within a single "barrel" of developing rat somatosensory cortex. J Physiol (Lond) 521:169-190.

Fleidervish IA, Binshtok AM, Gutnick MJ (1998) Functionally distinct NMDA receptors mediate horizontal connectivity within layer 4 of mouse barrel cortex. Neuron 21:1055-1065.

Fox K, Schlaggar BL, Glazewski S, O'Leary DDM (1996) Glutamate receptor blockade at cortical synapses disrupts development of thalamocortical and columnar organization in somatosensory cortex. Proc Natl Acad Sci USA 93:5584-5589.

Fujimiya M, Kimura H, Maeda T (1986) Postnatal development of serotonin nerve fibers in the somatosensory cortex of mice studied by immunohistochemistry. J Comp Neurol 246:191-201.

Gil Z, Connors BW, Amitai Y (1997) Differential regulation of neocortical synapses by neuromodulators and activity. Neuron 19:679-686.

Gil Z, Connors BW, Amitai Y (1999) Efficacy of thalamocortical and intracortical synaptic connections: quanta, innervation, and reliability. Neuron 23:385-397.

Gutnick MJ, Connors BW, Prince DA (1982) Mechanisms of neocortical epileptogenesis in vitro. J Neurophysiol 48:1321-1335.

Hannan AJ, Blakemore C, Katsnelson A, Vitalis T, Huber KM, Bear M, Roder J, Kim D, Shin HS, Kind PC (2001) PLC-beta1, activated via mGluRs, mediates activity-dependent differentiation in cerebral cortex. Nat Neurosci 4:282-288.

Harris RM, Woolsey TA (1981) Dendritic plasticity in mouse barrel cortex following postnatal vibrissa follicle damage. J Comp Neurol 196:357-376.

Henderson TA, Woolsey TA, Jacquin MF (1992) Infraorbital nerve blockade from birth does not disrupt central trigeminal pattern formation in the rat. Brain Res Dev Brain Res 66:146-152.

Hoyer D, Clarke DE, Fozard JR, Hartig PR, Martin GR, Mylecharane EJ, Saxena PR, Humphrey PP (1994) International Union of Pharmacology classification of receptors for 5-hydroxytryptamine (Serotonin). Pharmacol Rev 46:157-203.

Iwasato T, Erzurumlu RS, Huerta PT, Chen DF, Sasaoka T, Ulupinar E, Tonegawa S (1997) NMDA receptor-dependent refinement of somatotopic maps. Neuron 19:1201-1210.

Iwasato T, Datwani A, Wolf AM, Nishiyama H, Taguchi Y, Tonegawa S, Knopfel T, Erzurumlu RS, Itohara S (2000) Cortex-restricted disruption of NMDAR1 impairs neuronal patterns in the barrel cortex. Nature 406:726-731.

Izumi Y, Benz AM, Zorumski CF, Olney JW (1994) Effects of lactate and pyruvate on glucose deprivation in rat hippocampal slices. NeuroReport 5:617-620.

Jacobson S (1963) Sequence of myelination in the brain of the albino rat. A. Cerebral cortex thalamus and related structures. J Comp Neurol $121: 5-29$.

Katz LC, Shatz CJ (1996) Synaptic activity and the construction of cortical circuits. Science 274:1133-1138.

Kidd FL, Isaac JT (1999) Developmental and activity-dependent regulation of kainate receptors at thalamocortical synapses. Nature 400:569-573

Laurent A, Goaillard JM, Hen R, Ropert N (1999) Inhibition présynaptique de la transmission thalamocorticale glutamatergique par des récepteurs 5-HT1B pendant le développement des tonneaux du cortex somesthésique primaire de souris. Société des Neurosciences, Marseille, May.

Lebrand C, Cases O, Adelbrecht C, Doye A, Alvarez C, El Mestikawy S, Seif I, Gaspar P (1996) Transient uptake and storage of serotonin in developing thalamic neurons. Neuron 17:823-835.

Lebrand C, Ezan P, Gaspar P (1998a) Developmental time course of the serotonin $1 \mathrm{~B}$ receptor expression in the mouse thalamus. Eur $\mathrm{J}$ Neurosci $10: 136$.

Lebrand C, Cases O, Wehrle R, Blakely RD, Edwards RH, Gaspar P (1998b) Transient developmental expression of monoamine transporters in the rodent forebrain. J Comp Neurol 401:506-524.

Leslie MJ, Bennett-Clarke CA, Rhoades RW (1992) Serotonin 1B receptors form a transient vibrissa-related pattern in the primary somatosensory cortex of the developing rat. Brain Res Dev Brain Res 69:143-148.
Lieske V, Bennett-Clarke CA, Rhoades RW (1999) Effects of serotonin on neurite outgrowth from thalamic neurons in vitro. Neuroscience 90:967-974.

Lotto B, Upton L, Price DJ, Gaspar P (1999) Serotonin receptor activation enhances neurite outgrowth of thalamic neurones in rodents. Neurosci Lett 269:87-90.

Lubke J, Egger V, Sakmann B, Feldmeyer D (2000) Columnar organization of dendrites and axons of single and synaptically coupled excitatory spiny neurons in layer 4 of the rat barrel cortex. J Neurosci 20:5300-5311.

Manabe T, Wyllie DJ, Perkel DJ, Nicoll RA (1993) Modulation of synaptic transmission and long-term potentiation: effects on paired pulse facilitation and EPSC variance in the CA1 region of the hippocampus. J Neurophysiol 70:1451-1459.

Maroteaux L, Saudou F, Amlaiky N, Boschert U, Plassat JL, Hen R (1992) Mouse 5HT1B serotonin receptor: cloning, functional expression, and localization in motor control centers. Proc Natl Acad Sci USA 89:3020-3024.

McCormick DA (1992) Neurotransmitter actions in the thalamus and cerebral cortex and their role in neuromodulation of thalamocortical activity. Prog in Neurobiol 39:337-388.

McCormick DA, Prince DA (1987) Post-natal development of electrophysiological properties of rat cerebral cortical pyramidal neurones. J Physiol (Lond) 393:743-762.

McCormick DA, Connors BW, Lighthall JW, Prince DA (1985) Comparative electrophysiology of pyramidal and sparsely spiny stellate neurons of the neocortex. J Neurophysiol 54:782-806.

Métin C, Denizot JP, Ropert N (2000) Intermediate zone cells express calcium-permeable AMPA receptors and establish close contact with growing axons. J Neurosci 20:696-708.

Mooney RD, Shi MY, Rhoades RW (1994) Modulation of retinotectal transmission by presynaptic 5-HT1B receptors in the superior colliculus of the adult hamster. J Neurophysiol 72:3-13.

Osterheld-Haas MC, Van der Loos H, Hornung JP (1994) Monoaminergic afferents to cortex modulate structural plasticity in the barrelfield of the mouse. Dev Brain Res 77:189-202.

Ozawa S, Kamiya H, Tsuzuki K (1998) Glutamate receptors in the mammalian central nervous system. Prog Neurobiol 54:581-618.

Pickard GE, Smith BN, Belenky M, Rea MA, Dudek FE, Sollars PJ (1999) 5-HT1B receptor-mediated presynaptic inhibition of retinal input to the suprachiasmatic nucleus. J Neurosci 19:4034-4045.

Prakash N, Vanderhaeghen P, Cohen-Cory S, Frisen J, Flanagan JG, Frostig RD (2000) Malformation of the functional organization of somatosensory cortex in adult ephrin-A5 knock-out mice revealed by in vivo functional imaging. J Neurosci 20:5841-5847.

Rhoades RW, Bennett-Clarke CA, Shi MY, Mooney RD (1994) Effects of 5-HT on thalamocortical synaptic transmission in the developing rat. J Neurophysiol 72:2438-2450.

Rhoades RW, Chiaia NL, Lane RD, Bennett-Clarke CA (1998) Effect of activity blockade on changes in vibrissae-related patterns in the rat's primary somatosensory cortex induced by serotonin depletion. J Comp Neurol 402:276-283.

Roerig B, Katz LC (1997) Modulation of intrinsic circuits by serotonin 5-HT3 receptors in developing ferret visual cortex. J Neurosci 17:8324-8338.

Roerig B, Nelson DA, Katz LC (1997) Fast synaptic signaling by nicotinic acetylcholine and serotonin 5-HT3 receptors in developing ferret visual cortex. J Neurosci 17:8353-8362.

Rozov A, Burnashev N (1999) Articles Polyamine-dependent facilitation of postsynaptic AMPA receptors counteracts paired-pulse depression. Nature 401:594-598.

Salichon N, Gaspar P, Upton AL, Hamon M, De Maeyer E, Picaud S, Murphy DL, Möessner R, Lesch KP, Hen R, Seif I (2001) Excessive activation of 5-HT1B receptors disrupts the formation of sensory maps in monoamine oxidase A and 5-HT transporter knockout mice. J Neurosci 21:884-896.

Saudou F, Amara DA, Dierich A, LeMeur M, Ramboz S, Segu L, Buhot MC, Hen R (1994) Enhanced aggressive behavior in mice lacking 5-HT1B receptor. Science 265:1875-1878.

Schlaggar BL, Fox K, O Leary DD (1993) Postsynaptic control of plasticity in developing somatosensory cortex. Nature 364:623-626.

Stern P, Edwards FA, Sakmann B (1992) Fast and slow components of unitary EPSCs on stellate cells elicited by focal stimulation in slices of rat visual cortex. J Physiol (Lond) 449:247-278.

Stuart GJ, Dodt HU, Sakmann B (1993) Patch-clamp recordings from the soma and dendrites of neurons in brain slices using infrared video microscopy. Pflügers Arch 423:511-518.

Van der Loos H, Woolsey TA (1973) Somatosensory cortex: structural alterations following early injury to sense organs. Science 179:395-398.

Vitalis T, Cases O, Callebert J, Launay JM, Price DJ, Seif I, Gaspar P (1998) Effects of monoamine oxidase A inhibition on barrel formation in the mouse somatosensory cortex: determination of a sensitive developmental period. J Comp Neurol 393:169-184.

Voigt MM, Laurie DJ, Seeburg PH, Bach A (1991) Molecular cloning 
and characterization of a rat brain cDNA encoding a 5hydroxytryptamine1B receptor. EMBO J 10:4017-4023.

Weliky M, Katz LC (1999) Correlational structure of spontaneous neuronal activity in the developing lateral geniculate nucleus in vivo. Science 285:599-604.

Welker C (1971) Microelectrode delineation of fine grain somatotopic organization of $(\mathrm{SmI})$ cerebral neocortex in albino rat. Brain Res 26:259-275.

Welker E, Armstrong-James M, Bronchti G, Ourednik W, GheorghitaBaechler F, Dubois R, Guernsey DL, Van der Loos H, Neumann PE (1996) Altered sensory processing in the somatosensory cortex of the mouse mutant barrelless. Science 271:1864-1867.

White EL (1978) Identified neurons in mouse Sml cortex which are postsynaptic to thalamocortical axon terminals: a combined Golgielectron microscopic and degeneration study. J Comp Neurol 181:627-661.

Woolsey TA, Van der Loos H (1970) The structural organization of layer IV in the somatosensory region (SI) of mouse cerebral cortex. The description of a cortical field composed of discrete cytoarchitectonic units. Brain Res 17:205-242.

Woolsey TA, Wann JR (1976) Areal changes in mouse cortical barrels following vibrissal damage at different postnatal ages. J Comp Neurol 170:53-66.

Zhang ZW, Deschenes M (1997) Intracortical axonal projections of lamina VI cells of the primary somatosensory cortex in the rat: a single-cell labeling study. J Neurosci 17:6365-6379. 